\title{
A forradalom racionalitása
}

Az európai államok történelmében 950 és 1950 között volt négy olyan rövidebb korszak, amikor feltűnően gyors társadalmi, politikai és gazdasági változások zajlottak le. Mindegyik ilyen időszakot megelőzte valamilyen nagy jelentőségű találmány vagy újítás bevezetése az információs és kommunikációs technológia területén. Ez a tanulmány az eseményeknek ezt a két sorozatát összekapcsolja egy racionális forradalom-elmélettel, miszerint a társadalmi erőforrások allokációjához szükséges információ előállításának optimális rendszere az állandó költségek és a hálózati hatások viszonylagos fontosságától függ. Ezeknek a paramétereknek a megváltozásai négyféle típusú - kontraktuális, konszenzuális, preventív, illetve preskriptív - forradalmat válthatnak ki. Az egyes típusok megfelelnek a szóban forgó, történelmi jelentőségű változásokat hozó korszakok alapvető jellemvonásainak.

\section{Szerzői információ:}

\section{Leonard M. Dudley}

A Torontoi Egyetemen politikatudományi és közgazdaságtani diplomát szerzett, majd a Yale Egyetemen doktorált. 1981 óta a Montreáli Egyetemen elsősorban gazdaságtörténeti és nemzetközi kereskedelmi kurzusokat vezet. Vendégprofesszorként és kutatóként múködött a Bambergi, a Freiburgi és a Drezdai Egyetemen Németországban és a Párizsi Politikatudományi Intézetben. Tanácsadóként részt vett több latin-amerikai országban nemzetközi szervezetek által indított kutatási és fejlesztési programokban. Angol, francia, spanyol és német nyelven publikál. Könyveiben az információs technológiák és az erôszak hatásaival, illetve a külföldi segélynyújtások kérdéseivel foglalkozott (The Word and the Sword: How Techniques of Information and Violence Have Shaped Our World; The Supply of Canadian Foreign Aid: Explanation and Evaluation). Tanulmányai, cikkei számos kanadai és nemzetközi folyóiratban jelentek meg.

Így hivatkozzon erre a cikkre:

Dudley, Leonard. „A forradalom racionalitása”.

Információs Társadalom III, 3-4. szám (2003): 6-38.

$\mathbf{L}$

https://dx.doi.org/10.22503/inftars.III.2003.3-4.1

A folyóiratban közölt müvek

a Creative Commons Nevezd meg! - Ne add el! - Így add tovább! 4.0

Nemzetközi Licenc feltételeinek megfelelően használhatók. 


\section{A forradalom racionalitása}

Az európai államok történelmében 950 és 1950 között volt négy olyan rövidebb korszak, amikor gyors társadalmi, politikai és gazdasági változások zajlottak le. Mindegyik ilyen idôszakot megelốzte valamilyen nagy jelentôségú találmány vagy újítás bevezetése az információs és kommunikációs technológia területén. Ez a tanulmány az eseményeknek ezt a két sorozatát összekapcsolja egy racionális forradalomelmélettel, miszerint a társadalmi erőforrások allokációjához szükséges információ előállításának optimális rendszere az állandó költségek és a hálózati hatások viszonylagos fontosságától függ. Ezeknek a paramétereknek a megváltozásai négyféle típusú - kontraktuális, konszenzuális, preventiv, illetve preskriptí - forradalmat válthatnak ki.* Az egyes típusok megfelelnek a szóban forgó, történelmi jelentôségú változásokat hozó korszakok alapvető jellemvonásainak.

A mai Párizs lombos fákkal szegélyezett, széles körútjai a tizenkilencedik század közepén épültek ki, miután az addigi zsúfolt, szûk utcácskákkal szabdalt lakókörzeteket III. Napóleon kezdeményezésére lerombolták. Az 1848. évi februári forradalom, majd ezt követôen a Bonaparte Napóleon unokaöccsét hatalomra segító államcsíny hatásai nem korlátozódtak a városi újjáépítésekre. Ebben az idôszakban kezdôdött meg Franciaországban a társadalmi, politikai és gazdasági élet hasonlóan mélyreható átformálása. A francia állam, amely tevékenységét mindaddig elsôsorban a honvédelemre és a tulajdonjogok védelmére korlátozta, elkezdett aktívan foglalkozni a társadalmi jólét, a közegészségi intézmények és a közoktatás fejlesztésével. Ahelyett, hogy egy szűk földbirtokos osztály szavazataira építette volna hatalmát, intézkedéseit - a férfi lakosság teljes körére kiterjesztett szavazati jogokon keresztül -, a közvélemény jóváhagyásának elnyerésével törvényesítette. Közpénzek nagyarányú felhasználásával olyan nagyszabású infrastrukturális beruházásokat kezdtek finanszírozni, mint amilyen például a vasútépítés volt, amit szükségesnek véltek a társadalmi és az ipari fejlődéshez. ${ }^{1}$ Az ilyen változások nem korlátozódtak csupán Franciaországra. 1848-ban a forradalom Franciaországból kiindulva végigsöpört Közép-Európa nagy ré-

* A szerzốdéses, a megegyezésen alapuló, a megelóző és az előiró jelzők a forradalomhoz társítva - ez utóbbival szöges ellentétben álló jelentésük folytán - majdnem olyan meghökkentôen hatnak, mint ha „békés háborúról” vagy „előzetes utóhatásról” beszélnénk, hiszen a magyar köznyelvi szóhasználatban a forradalom éppen a szerzốdés vagy a megegyezés hiányát jelzi. A fordításban ezért célszerưnek látszik megtartani a tudományos megközelítésre és elméleti értelmezésre utaló latin eredetû terminusokat. Az angol nyelvű eredeti szövegben szereplố „preemptive” kifejezést, amit az elôvételi, kezdeményezô vagy megelőzô jelzôkkel lehetne magyarra fordítani, a hasonló jelentésû és a kontextusba jobban illeszkedő „preventív” szóval kísérelem meg visszaadni, mivel a magyar szaknyelvben nincs pontosabb és már meghonosodott latinos hangzású megfelelője. A szerző egyébként a tanulmányban részletesen kifejti és szabatosan értelmezi ezeket a fogalmakat. $-A$ ford.

Sok francia történész vonakodik attól, hogy III. Napóleon rendszerének innovációkat tulajdonítson (ld. például Plessis 1985:142, 143 és Girard 1986). Mindazonáltal nyomós okok szólnak amellett, hogy a császárt társadalmi reformernek tekintsük (ld. Borneque-Winandy 1980, Miquel 1992). 
szén: Németországban, Ausztriában és Észak-Itáliában az emberek szintén az utcákra vonultak. A fontosabb európai fốvárosokban - csakúgy, mint ahogyan a párizsi bulvárokról véve mintát, némi késéssel utánozták a „Második Birodalom” építészeti stílusát - igyekeztek átvenni a liberális állam intézményeit is.

Mi idézi elő az olyan folytonossági törések bekövetkezését a történelemben, mint amilyenek az 1848. évi forradalmak voltak? Ez a tanulmány azt a gondolatot veti fel, hogy az ilyen események korábbi vizsgálataiból hiányzik egy fontos elem. 1788 és 1846 között például a fốbb párizsi napilapok összesített példányszáma tízezernél kevesebbről több mint 145 ezerre növekedett (Popkin 1989:145; Bellanger 1969:100, 146). Vizsgálódásunkat általánosabb szintre emelve, 950 és 1950 között az információs és kommunikációs technológia területén nagy jelentôségú újítások és találmányok négy elkülönült sorozatát figyelhetjük meg Európában. ${ }^{2}$ Mindegyik ilyen innovációs hullám nyomában forradalmi társadalmi változások robbantak ki. Ez a tanulmány - elméleti alapokra támaszkodó összehasonlító történelmi megközelítést alkalmazva, ahogyan Skocpol (Skocpol 1979:33-40) javasolta - az információs és kommunikációs technológia megújulása és a forradalom között elvileg lehetséges kapcsolatokat vizsgálja. $^{3}$

Az 1848-as események megmagyarázásában a korábbi forradalomelméletek nehézségekbe ütköztek. Tilly ('Tilly 1993:7-9) eljutott addig a megállapításig, hogy a forradalom általános elméletét nem lehet felállítani. A forradalom szerinte előre nem látható esemény: csak azokat a tényezóket lehet számba venni, amelyek hatással vannak az államhatalom erôszakos megdöntésére és átvételére irányuló kísérletek valószínúségére, további más tényezốkkel együtt, amelyek annak a valószínűségére vannak befolyással, hogy az ilyen törekvések sikerrel járnak. Az elốbbi tényezôk közé Tilly az adók mértékét, a kultúrpolitikát és az uralkodók hatalmának szilárdságát; az utóbbiak közé pedig az állam rendelkezésére álló kényszerítő eszközöket sorolta (Tilly 1993:237-242). Az 1848. évi sikeres forradalmakban azonban ezeknek a tényezőknek egyike sem játszott jelentősebb szerepet. ${ }^{4}$

Goldstone (Goldstone 1991) álláspontja szerint a forradalmak magyarázatakor azt kell kulcstényezônek tekinteni, hogy valamely társadalom lélekszáma milyen arányban áll a rendelkezésre álló forrásokkal. Amikor valamely közösség képtelen megoldani a népesség-növekedés okozta nyomásból fakadó problémákat, az államhatalom összeomlik. Goldstone kimutatta, hogy a gabonaárak a bérekhez képest mind az 1640-es években lezajlott angol forradalom, mind az 1789-es francia forradalom elôtt meredeken megemelkedtek. 1846-ban és 1847-ben Franciaországban és Németországban hasonlóképpen leestek a reálbérek, 1848 nyarára azonban már megkezdődött egy hosszantartó fellendülés a termelés, a foglalkoztatottság és a reálbérek terén

2. Mokyr (Mokyr 1990:294-295) különbséget tesz a makro-invenciók, vagyis a meglévố technológiáktól lényegileg eltérố új elgondolások és a mikro-invenciók, vagyis a meglévố technológiák kisebb módosításai között.

3. Ebben a tanulmányban feltételezzük, hogy a technológiai változások az információs és kommunikációs technológia területén külsổ eredetűek (azt a kérdést illetôen, hogy maga az információs és kommunikációs technológia hogyan és miért fejlődik, ld. Dudley 1999).

4. A fegyveres felkelések Magyarországon és Lombardia-Velence tartományaiban az osztrák uralom ellen nem voltak sikeresek. 
egyaránt (Craig 1989:124). Goldstone elmélete kevésbé sikeresen magyarázza, hogy az európai kontinensen a vihar elcsitultával miért igyekeztek az államfő́k - szinte kivétel nélkül - fontos engedményeket beiktatni az általuk kibocsátott alkotmányokba. ${ }^{5}$

A reálbér csak egyikét tükrözi azoknak az árfajtáknak, amelyeknek az ingadozásai társadalmi zavarokhoz vezethetnek. Nyugtalanságot okozhatnak más változások is, amelyek bekövetkezhetnek a közszolgáltatások árában (vagyis az adókulcs változásai), az olyan anyagi vagyontárgyak értékében, mint például a papírpénz, a bankjegyek (vagyis az infláció), vagy annak a költségeiben, hogy valaki az adott bérszínvonalon egyáltalán munkát találjon (azaz a munkanélküliség). Általánosabb szinten North (North 1990:86-91) kimutatta, hogy bármelyik ár fluktuációja valamely szerződés aláiróit arra késztetheti, hogy újratárgyalják a szerződést. Az újraszerződéshez néha szükség van azoknak a szabályoknak a megváltoztatására, amelyek szerint a szerződés tárgyát közelebbrốl meghatározzák, illetve a szerzôdés betartását kikényszerítik. Ha az ilyen szabályok megváltoztatását lehetővé tevő intézmények nem léteznek, akkor egy vagy több szerződő fél úgy dönthet, hogy a szerződés megváltoztatása céljából erôszakot alkalmaz. E szerint az „ügyleti költségekre” koncentráló megközelítés szerint tehát a forradalom a tökéletlen intézményekre adott válasz. Ilyen fajta érvelés azonban utólagosan szinte bármilyen radikális változás értelmezésére alkalmazható. Van azonban egy kérdés, amit nem tud olyan könnyen megmagyarázni, nevezetesen az, hogy hasonló körülmények között máskor miért nem tört ki forradalom. Például közvetlenül 1815 után Németországban és Franciaországban a reálbérek ugyanolyan alacsonyak voltak, mint 1846-ban és 1847-ben, de abban az idôszakban nem fenyegetett semmiféle felkelés veszélye (Goldstone 1991:293).

Mindegyik ilyen forradalomelméletben alapvető szerepet játszik a korlátozott racionalitás feltételezése. Az elméletek szerint a társadalmak hajlamosak olyan intézmények csapdájába esni, amelyek nem feltétlenül optimálisak - olyan értelemben, hogy a társadalom tagjainak nagy többsége valamilyen más struktúrát részesítene előnyben. ${ }^{6}$ Amikor sor kerül erôszakos változásokra, a lázadás vezetôiről talán feltételezhetô, hogy racionálisan cselekszenek, mivel a várható nyereségek számukra meghaladják azt az árat, amibe elérésük kerül (Tullock 1974). Követőiket tekintve azonban ezek az elméletek azt sugallják, hogy közülük a legtöbben valamely ideológia által motiválva, nem-racionálisan cselekszenek, hiszen a közremúködés költségei az ő számukra valószínúleg nagyobbak, mint a saját jólétüket érintő csekély többleti hatás.

\footnotetext{
Franciaországban III. Napóleont 1848 decemberében választották meg elnökké, ugyanazoknak a csoportoknak a segítségével, amelyek a júliusi monarchiát is támogatták. 1851. decemberi államcsínyét követôen III. Napóleon olyan alkotmányt bocsátott ki, amely általános választójogot biztosított a felnổtt korú férfilakosság számára. Poroszországban a király jóváhagyásával 1848 decemberében hatályba léptetett alkotmány, amit 1850-ben átdolgoztak, ugyancsak általános választójogot adott a kétkamarás törvényhozás alsó házának megválasztásához. Ausztriában a császár által 1848-ban aláirt chartát nem iktatták hatályba, de késốbb az 1860-as években kibocsátott alkotmányos dokumentumok - beleértve az 1867. évi kiegyezést (Ausgleich), ami létrehozta az Osztrák-Magyar Monarchiát - hatályba léptek. Piedmontban II. Viktor Emmanuel 1849-ben jóváhagyta azt a liberális alkotmányt, amelyet elôdje 1848 elején adott ki.

6. Kuran (Kuran 1995) egy olyan módszerrel mutat rá a bizonytalan egyensúlyi helyzetek kitartó fennmaradására, amit ő maga „a preferenciák hamisításának” nevez. Ez úgy alkalmazható, hogy nyilvánosan felkarolnak olyan meggyổződéseket, amelyek különböznek az emberek valódi preferenciáitól. Ebben a tanulmányban ez a kérdés olyan értelemben merül fel, hogy az ilyen helyzetek vajon stabilak maradnake, amikor az emberek többsége valamely társadalomban ilyen helyzetben találja magát.
} 
Az efféle érvelés rövidebb időszakokra nézve, vagy az egyének számára nem fontos, ismeretlen vagy közvetlen társadalmi környezetükból kiszakított kérdésekben alkalmas lehet a tehetetlenség magyarázatára.? Az elégtelenül mûködô intézmények tartós fennmaradása azonban arra utal, hogy az emberek többsége nem képes tanulni az új információból. Ha nem így lenne, akkor - ahogy a ténylegesen meglévő és az elvileg lehetséges intézmények közötti rés tágul - egy bizonyos ponton mindenki felismerné, hogy részéről szerényebb erőfeszítés is várhatóan azzal arányos eredményeket hozna. Szociálpszichológiai kísérleti eredmények azt bizonyítják, hogy amikor a jutalmak növekednek, és figyelembe veszik a társadalmi környezetet is, a kísérleti alanyok valóban kölcsönhatásba lépnek egymással, mégpedig bizonyos optimalizációs modelleknek megfelelő módon (Smith 1991:884-888). Az 1848-as forradalmak példája azt mutatja, hogy közös cselekvés útján az egyének szerény költséggel jelentôs nyereséget tudnak elérni.

Röviden: úgy tűnik, hogy valami hiányzik a forradalmak legtöbb eddigi értelmezéséból. Vajon az olyan társadalmi és politikai fejleményeket, mint amilyenek 1848ban történtek, mi választja el számos más politikai rendszerváltozástól? Hirshleifer (Hirschleifer 1980) a „szocialitásnak” nevezett társulási hajlam három alapvető típusát különböztette meg. Ezek közül az egyik a dominancia elvén alapul: bizonyos egyedek megkísérlik a többieket alárendelni saját maguknak. A legyốzött egyed inkább elfogadja alávetettségét, mintsem hogy halálos küzdelmet folytasson ez ellen. A társadalmi kölcsönhatások második típusa a tulajdonjogokra épül. A potenciális behatolók hajlanak arra, hogy tiszteletben tartsák az olyan vagyontárgyakat, javakat vagy területeket, amelyek már valaki másnak a birtokában vannak, mert tudják, hogy az utóbbi jelentôs energiákat fog azok védelmére fordítani. Az ilyen jogok alkotják az önkéntes csere bázisát. A szocialitás harmadik formája a közösségi osztozkodás elvén alapul. Ebben az esetben az egyének megosztják a rendelkezésükre álló forrásokat másokkal is, ha nagy valószínúséggel számítani lehet a viszonzásra. ${ }^{8}$

Egy percnyi gondolkodás elvezethet annak belátásához, hogy a közösségi intézmények legfontosabb produktuma bármely társadalomban a források választható célokra fordításához felhasznált információ, vagyis az, amit allokatív információnak nevezhetünk. Az ilyen információk körében ténylegesen megkülönböztethetôk olyan kategóriák, amelyek megfelelnek a társadalmi kölcsönhatás Hirshleifer által meghatározott három típusának. A dominanciára épülő kapcsolatokban az információ parancsokból, azaz olyan utasításokból áll, amelyeket nem képviseleti jellegú csoportok bo-

7. Conlisk (Conlisk 1996:670-672) áttekinti azokat a kísérleti bizonyítékokat, amelyek az individuális racionalitás hipotézisével összeegyeztethetetlenek.

8. Az a gondolat, hogy a társadalmi viselkedésben megkülönböztethetô néhány különbözô típus, nem csupán Hirshleiferben merült fel. Mary Douglas (Douglas 1982) kidolgozta a társadalmi csoportok és rácsozatok olyan tipológiáját, miszerint a különbségeket két jellegzetesség határozza meg: elôször az egyének valamely zárt csoporthoz való kötődésének erőssége, másodszor pedig annak a mértéke, hogy az egyén élete mennyiben van kitéve külsố korlátozásoknak. Ennek eredményeként négyféle életmód különböztethetố meg: egalitárius, individualista, hierarchikus és fatalista. Az első kettô megfelel Hirshleifer közösségi osztozkodási, illetve tulajdonjogokra épülő típusainak, míg az utóbbi kettô lényegében nem más, mint a domináns, illetve az alárendelt egyén szerepe a dominanciára épülố társadalomtípusban. Thompson, Ellis és Wildavsky (Thompson-Ellis-Wildavsky 1990) kimutatták, hogy a kis számú létezô társadalomtípus eszméje Durkheimen át visszavezethető egészen Montesquieu-ig és Arisztotelészig. 
csátanak ki. Például a restauráció korában Franciaországban az arisztokraták szúk körére épülő kormányzatnak a legnagyobb ellenkezést kiváltó intézkedése egy 1824ben kibocsátott törvény bevezetése volt, ami az emigrált nemességnek - állami kölcsönkötvények kibocsátása útján, vagyis a kötvénytulajdonosok kárára - kompenzációt biztosított az 1789. évi forradalom során elszenvedett veszteségeiért. A tulajdonjogokra épülő kölcsönhatások esetében a társadalmilag létrehozott információ árakból és átruházható tulajdonjogokból tevődik össze - ezek képezik a piaci csereakciók alapját. Úgy tûnik, hogy 1848-ban az élelmiszerek árának a gyenge termésből adódó emelkedése siettette a politikai forrongások kitörését (Craig 1989:123). Végül pedig vannak olyan önkéntesen elfogadott sæabályok, amelyek szerint valamely közösségi csoport tagjai hajlandóak bizonyos költségeken és hasznokon osztozkodni. Ezek a szabályok bármely társadalomban részben szociálisan jóváhagyott viselkedési mintákból állnak, ilyen például a jótékonyság a szükséget szenvedốk iránt. ${ }^{9}$ Európában a tizenkilencedik század közepétől kezdve új elemként jelent meg a nép által választott kormányok beavatkozása az észlelt piaci múködési zavarok korrekciója érdekében. III. Napóleon kormánya például arra ösztönözte a munkáltatókat, hogy dolgozóik számára létesítsenek nyugdíjalapokat. Ugyancsak az állam közremúködésével biztosították a városi lakosság számára a tiszta ivóvíz-szolgáltatást és a csatornázást, valamint a szegény családok számára az iskolai tandíjak kifizetését is (Miquet 1992:135-136; Borneque-Winandy 1980:50).

Minden komplex társadalom felhasználja az allokatív információ mindhárom típusát, az utasítások, az árak és a szabályok viszonylagos fontossága azonban nagy változatosságot mutathat. Mivel a kihelyezendő erőforrások mennyisége rövid távon állandó, az allokativ információ valamelyik típusának fontosságában bekövetkezö bármilyen növekedésnek együtt kell járnia legalább egy másik típus fontosságának a csökkenésével. Ennek a tételnek a vizsgálatához e tanulmány első része felvázolja a kezdeti feltételeket: elôször is bemutatja Európa politikai helyzetét Nagy Károly uralkodásának idején, majd definiálja a forradalom fogalmát, ezt követôen pedig leírja az információs és kommunikációs technológia helyzetét az adott korszakban. A második rész áttekinti az európai történelem ez után következő ezredévének négy hosszabb időszakából leszűrt bizonyítékokat arra nézve, hogy mindegyik forradalmi hullám kitörését megelőzte valamilyen nagyobb jelentőségú találmány vagy újítás bevezetése az információs és kommunikációs technológia területén. Végül a harmadik rész a játékelméletet alkalmazva azt illusztrálja, hogy az információs és kommunikációs technológiai innovációk hogyan válthatták ki a forradalmakat azáltal, hogy megváltoztatták a különféle közremúködések kifizetődésének rangsorolását abban a nem-kooperatív jellegú játékban, amivel a társadalom létrehozza az allokatív információt.

9. III. Napóleon példát mutatott azzal, hogy évi fizetésének felét a szegényeknek adományozta (Borneque-Winandy 1980:49). 


\section{EURÓPA HAJNALA}

Ha van olyan pillanat a történelemben, amelyhez Európa születése, illetve ennek a Római Birodalom utódállamaitól megkülönböztető értelemben vett felismerése köthetô, akkor ez a 750 körüli időszakra tehető, amikor a frank királyok megkezdték politikai és katonai beavatkozásaikat az Alpoktól délre fekvố területeken (Davies 1996:288-290). Vegyük szemügyre Európát ebben az időszakban, vizsgáljuk meg a forradalom fogalmát, majd tekintsük át az akkori információs és kommunikációs technológia helyzetét.

\section{Kezdeti feltételek}

A nyolcadik századi Nyugat-Európában a döntéshozatal méginkább centralizált volt, mint korábban, a késôi Római Birodalom idején. Neustria, Burgundia és Austrasia majordomusa*, Kis Pipin 751-ben elûzte trónjáról az utolsó Meroving uralkodót és Soisson-nál felkent királlyá koronáztatta magát. A frankok királyságában nem volt adminisztratív bürokrácia; a hatalom ehelyett a király személyében összpontosult. Pipin uralma idején az egyházmegyék rendszere, melyben a püspökök kinevezését a király ellenőrizte, kiterjedt a Rajnától keletre fekvő germán területekre is. A világi tisztségviselést illetốen hasonló volt a helyzet, csak Bavaria tartományának lehetett helyileg választott vezetóje, és még az is kényszerítve volt - megalázó módon - formálisan elismerni Pipin fennhatóságát (Fouracre 1995:99). Ami a társadalmi állapotokat illeti, a népesség általános csökkenése és a városias települések hanyatlása, ami már a késôi Római Birodalomban is érzékelhetố volt, a barbár uralom elsố évszázadaiban folytatódott. 650-re Nyugat-Európa lakóinak száma a korai Római Birodalom lélekszámának a felére csökkent (Russel 1985:36). A népességfogyás a városokat érintette a legsúlyosabban, különösen az Alpoktól északra, ahol számos település gyakorlatilag elnéptelenedett. A gazdasági élet terén a városok hanyatlásával erôteljes zuhanás következett be a helyi és a távolsági kereskedelemben egyaránt. A vidéki területekre mind a rabszolgamunkával múvelt nagy gazdaságokban, mind a kisebb szabad birtokokon az önellátó gazdálkodás volt általánosan jellemző (Verhulst 1995:488-489).

\section{A forradalom fogalma}

Az elmúlt ezredév során a legfontosabb társadalmi, gazdasági és politikai változások a legtöbb európai államban - mint a következố részben látni fogjuk - rövid korszakokra koncentrálódtak. Ezek vajon forradalomnak tekinthetők? Zimmermann (Zimmermann 1983:298) olyan meghatározást fogalmazott meg, amit valószínúleg sok társadalomtörténész elfogadna: „A forradalom az uralkodó elit sikeres megbukta-

* A Merovingok uralkodása idején a Frank Birodalom nyugati részét Neustriának, keleti részét pedig Austrasiának nevezték. A majordomus (háznagy, udvarmester) a korai középkori Nyugat-Európában a (késốbbi) magyar nádori rangnak körülbelül megfelelố magas közjogi méltóság volt. $-A$ ford. 
tása egy új elit által, amely a hatalom átvétele után alapvetően megváltoztatja a társadalom szerkezetét és ezzel a hatalom szerkezetét is." Zimmermann 1600-tól számítva hat olyan eseményt azonosított az európai történelemben, ami megfelel ennek a meghatározásnak: az 1640 és 1649 között lezajlott és az 1688-1689. évi angol forradalmakat, az 1789-ben, 1830-ban és 1848-ban kitört francia forradalmakat és az 1917 novemberében végbement orosz forradalmat. Ha a vizsgált időhorizontot kiterjesztenénk még egy évszázaddal korábbra, valószínủleg hozzáadódna ehhez a sorozathoz az Egyesült Tartományok* Spanyolország elleni felkelése is (Tilly 1993:3. fejezet).

A forradalomnak ez a meghatározása azonban túlságosan szúkre szabott lehet. Voltak más, nagyobb forrongások is, mint például a harmincéves háború vagy az 1905 ös orosz forradalom. Voltak továbbá olyan kevésbé erốszakos események, mint például az 1832. évi reformtörvény bevezetése** vagy Mussolini, Hitler és Franco hatalomátvétele, amelyek szintén gyors társadalmi átrendeződéshez vezettek. ${ }^{10}$ Mint fentebb már utaltunk rá, a forradalom meghatározható olyan gyors ütemben lezajló változásként is, ami $a$ z utasitások, aะ árak és aะ önként elfogadott szabályok viszonylagos fontosságában következik be egy társadalmon belül. Egy ilyen meghatározás felölelne bármilyen fundamentális társadalmi változást, feltéve, ha az elegendố gyorsasággal történik; ennek viszont egyenes folyománya lenne, hogy a gazdasági, társadalmi és politikai forradalmakat ne elkülönült jelenségeknek, hanem egymással kölcsönös összefüggésben álló eseményeknek lássuk.

Igen fontos tényezố a tanulmányozott idôszak hosszúsága is. A forradalommal kapcsolatos újabb történettudományi vizsgálódások, például Goldstone (Goldstone 1986:1991), Zimmermann (Zimmermann 1990) és Tilly (Tilly 1993) kutatásai csak a modern korra szorítkoznak. Mindazonáltal - mint a kanadai gazdaságtörténész Harold Innis rámutatott - ugyanilyen mélyreható változások történtek a középkorban is. A tizenkettedik században az itáliai városok képesek voltak felszabadítani magukat a német császár uralma alól (Innis 1951:22). Ezt követôen a német hercegek felkelése II. Frigyes ellen a német birodalom összeomlásához vezetett (Innis 1950:161). Toljuk hát vissza az időküszöböt egészen addig, hogy áttekinthessünk egy egész ezredévet, 950-től 1950-ig.

\section{Információs és kommunikációs technológiák}

Az elmúlt évezredben lejátszódott társadalmi átalakulásokkal foglalkozó tanulmányok nagy részében a kutatók figyelme elsiklik a technológiai változások fölött. Milyen technológiákat kellene tekintetbe vennünk, ha a korai középkori Európát vizsgáljuk? Bresnahan és Trajtenberg (Bresnahan-Trajtenberg 1995) „általános célú

* Németalföld északkeleti részei, a késôbbi Hollandia. - A ford.

**A Whig kormányzat Charles Grey miniszterelnöksége idején Angliában beiktatott törvénye, ami a brit nagyvárosokban szavazati jogokat biztosított a középosztály képviseloinek. $-A$ ford.

10. Taylor (Taylor 1980(2)) a tizenkilencedik század második negyedében Nagy-Britanniában lezajlott forradalmi mozgalmakat tanulmányozta. Tilly (Tilly 1993:240) a fasiszták és a nácik hatalomátvételét forradalmi eredményként írta le. 
technológiának" tekinti mindazokat a módszereket, amelyek alapvető fontosságúak a termelési folyamatok és a termékek széles körének múködésében, illetve felhasználásában. ${ }^{11}$ Több évtizeddel ezelőtt Harold Innis (Innis 1950; 1951) kimutatta, hogy azok a technológiák, amelyeket Perez (Perez 1985) és Freeman (Freeman 1994) információs és kommunikációs technológiaként definiáltak, éppen ilyen szerepet játszanak, mivel meghatározzák, hogy az információt hogyan raktározzák az időben, hogyan továbbítják a térben, és hogyan dekódolják abból a célból, hogy megértsék azok, akik felhasználják (Dudley 1995).

Innis szemléletmódjának megvilágítása végett vizsgáljuk meg egyenként Európa koraközépkori információs rendszerének ezeket a dimenzióit. A raktározási költségek (beleértve a visszanyerés költségeit is) nagyjából állandó költségek, amelyek viszonylag érzéketlenek a tárolandó információ mennyiségére. Ezek elsôsorban a kódolási eljárás bonyolultságától és annak szabványosítási szintjétôl függenek. 771-ben, amikor Nagy Károly a frankok királyságának egyedüli uralkodója lett, az ilyen tárolási költségek - lényegében annak a csoportnak a képzési és eltartási költségei, akik tudtak latinul írni és olvasni - nagyon magasak voltak. Ennek egyik oka az volt, hogy Nyugat-Európa különböző régióiban a beszélt latin nyelv jelentős - mindegyik régióban más és más - eltéréseket mutatott a klasszikus latin nyelvtôl. Ebból adódóan a helyesírást gyakran nemcsak az egyes hangok visszaadására (vagyis fonetikusan), hanem egész szavak írásmódjára nézve (azaz logografikusan) is meg kellett tanulni (Wright 1997:270). Ehhez még hozzájárult a központozásnak és a szavak elválasztásának a hiánya, a gyakran nehezen olvasható, többszörösen lemásolt kéziratok használatával együtt, ami megnehezítette az információ-visszakeresést (Saenger 1990:448). ${ }^{12}$

Az átviteli költségek nagymértékben változó költségek, amelyek a kópiák számával és azzal a távolsággal egyenes arányban növekednek, amit az információ továbbításakor át kell hidalni. A nyolcadik század közepén az ilyen költségek szerények voltak, s fốleg azokból a kiadásokból tevődtek össze, amikre szükség volt, hogy a tisztségviselốket valamely szóbeli üzenet meghallgatása végett a királyi udvarba hozzák, vagy kiküldjék a missi dominici-nek nevezett hírvivó királyi futárokat. ${ }^{13}$ Ami a dekódolási költségeket illeti, ezek annak a hálózatnak a kiterjedésétől függenek, amit azok a személyek alkotnak, akik képesek az információ tárolására és visszanyerésére használt kódrendszert lefordítani a beszélt nyelvre. A Karoling korban Európa latin nyelvterületein egyfajta „nyelvi válság” jelei mutatkoztak. A beszélt nyelv kezdett annyira különbözôvé válni az írott latin nyelvtôl, hogy a latint a legtöbb esetben nem lehetett

11. Lipsey és szerzôtársai (Lipsey et al. 1998) az ilyen technológiák négy jellegzetességét azonosították: egyszerúen kezdődnek, összetettebb formákba fejlődnek, többféle célra használatosak, és sok más technológia mellett kiegészítố szerepet töltenek be.

12. Mivel a tárolási költségek magasak voltak, az írástudásban a késôi Római Birodalom szintjéhez képest erốteljes zuhanás következett be. A Codices Latini Antiquiores adatai azt mutatják, hogy Európa kontinentális részén az idôszámításunk kezdetétôl 700-ig tartó idôszakból körülbelül 1750 latin nyelvû́ kézirat maradt fenn, ami évtizedenként átlagosan 25 kéziratnak felel meg. A 700 és 750 közötti fél évszázadból azonban ma mindössze öt ilyen dokumentum létezik, ami évtizedenként átlagosan egyet jelent (Ganz 1987:26, 27). Az alapvetô fontosságú információkat centralizált formában az uralkodók emlékezete tárolta, néhány írásos feljegyzéssel támogatva (Stock 1983:16).

13. Ezeket a futárokat kettesével küldték ki, hogy eljuttassák a parancsokat egy bizonyos régióba. Az egyik közülük világi fốur, a másik pedig egyházi személy volt. (Heer 1975:39). 
többé a nép anyanyelvének tekinteni (Bannyard 1995:698-699). Ennek megfelelően az írott információ terjedésére gyakorolt hálózati hatások nem voltak elegendốen erốsek ahhoz, hogy valódi ösztönzést adjanak az írás-olvasás tanulásához.

\section{AZ EURÓPAI FORRADALMAK ÉS AZ INFORMÁCIÓS TECHNOLÓGIA}

A 950-tôl 1950-ig terjedô ezredév során a fontosabb európai államok mélyreható változások sorozatán mentek keresztül. Vizsgáljuk meg ezeket egyenként, különös figyelmet fordítva a hozzájuk kötődő változásokra az információs és kommunikációs technológia területén.

\section{Kontraktuális forradalom}

A feudalizmust, a középkor nagy társadalmi átalakulását gyakran a Karoling-kortól számítják (ld. például Cameron 1993:45). Hat évtizeddel ezelốtt azonban Bloch (Bloch 1939/1994:97-114) azt állította, hogy két feudális kor volt: az elsô a nyolcadik századtól kezdődően, amikor a Karoling királyok a vazallusaiknak - viszonzásul azok katonai szolgálataiért - földet adtak, a második pedig a tizenegyedik századtól számítva, amikor a húbéri birtokok urainak sikerült saját területükön mindenféle tevékenységet ellenőrzésük alá vonni. Újabb kutatások arra utalnak, hogy az igazi feudalizmus korának ezek közül a másodikat tekinthetjük, amikor a várurak és lovagjaik képesek voltak hatalmukba keríteni a korábban szabad földbirtokokat (Poly-Bournazel 1991:510). 1050 után először talán Normandiában, majd késôbb más régiókban is kifejlődött a hübéresi rendszer - az a gyakorlat, ami lehetôvé tette a feudális kötelmek következetes hierarchiájának megteremtését (Ganshof 1952:93). A tizenkettedik század elején kezdődött meg a hủbéres földbirtokosok jogait és kötelezettségeit részletesen meghatározó, írott oklevelek rendszeres használata (Ganshof 1952:73). A német területeken, ahol a húbéri rendszer nem szabad lovagokra, hanem szolgai státusú bérloók múvelt osztályára, az úgynevezett ministeriales-re épült, akik először az egyház birtokain túntek fel, a feudalizmus kialakulása és megszilárdulása némi késéssel ment végbe (Barraclough 1984:81,138). Végül, noha a szabad árak rendszere a feudális Európa új városaiban a kereskedelmi tevékenység terén továbbra is érvényben maradt, mind az egyháznak, mind a kereskedôk és iparosok céheinek sikerült végrehajtható írásbeli szabályokat lefektetni és elfogadtatni, amelyek korlátozták a piaci mechanizmus múködését. ${ }^{14}$

Az írásos szerződéseket elkezdték arra is felhasználni, hogy meghatározzák az alattvalók jogait uralkodóikkal kapcsolatban. Ha a pápa tekinthetố a szellemi fejedelemnek, akkor a pápaság és a német-római császár között 1122-ben megkötött wormsi konkordátum - a francia és az angol monarchák hasonló egyezményeivel együtt -

\footnotetext{
14. Verhulst (Verhulst 1995:504-509) leírja a kereskedelem újraéledését a hetedik századtól kezdve mind Észak-Európában, mind Dél-Európában. A kereskedôk és az iparosok céheinek múködéséről ld. Hibbert 1971 és Thrupp 1963.
} 
olyan alkotmányos dokumentumnak tekinthetô, ami a püspökök kinevezését illetően meghatározta a világi uralkodók jogait. Az 1183. évi konstanzi egyezmény értelmében Barbarossa Frigyes német császár egész sor szabadságjogot adományozott a Lombard Ligához tartozó észak-itáliai városoknak. IX. Alfonz leóni király 1188-ban olyan rendeleteket adott ki, amelyek fontos feudális privilégiumokat biztosítottak nemesei számára (Holt 1992:25). Mindegyik esetben az alattvalók lázadása vagy a lázadás fenyegetése volt az, ami az uralkodót arra késztette, hogy kötelezettséget vállaljon valamilyen írásbeli szerződés teljesítésére. Európa periférikus területein ezek a változások későbbre tolódtak. A német császár és a hercegek egészen az 1356. évi aranybulla* kibocsátásáig nem egyeztek bele abba, hogy a birodalmi választások szabályait írásban rögzítsék. Az orosz bojárok csak a tizenhetedik században voltak képesek stabil rendszert és a gyakorlatba átültethető írásos törvénykódexet létrehozni.

Korának legtökéletesebben kidolgozott társadalmi szerződése az 1215-ös angol Magna Charta volt, amit 1216-ban, 1217-ben és 1225-ben kisebb módosításokkal újra kiadtak. Ez a dokumentum tartalmazta azt a gondolatot, hogy az ország „saját földjének kommunája", a király pedig olyan személy, akinek a cselekedeteit korlátozni kell (Clanchy 1983:196-197). A Charta nem csupán a politikai jogokra szorítkozott; emellett lefektette azokat a feudális kötelmeket és feltételeket, amelyek szabályozták a föld birtoklását és átruházását, valamint az adósságok visszafizetését, előírták az árucikkek mérlegelési és egyéb mérési módszereit, továbbá megszabták azt is, hogy a kereskedők hogyan utazhattak áruikkal együtt. Ezek az átalakulások együttesen - tekintettel arra, hogy azok az írásos dokumentumok, amelyek részletesen meghatározták a szerződô felek elôjogait és kötelességeit, rendkívül fontos szerepet játszottak bennük - kontraktuális forradalomként írhatók le, melynek során az utasítások és az árak mechanizmusának múködését önkéntesen elfogadott szabályokkal részlegesen korlátozták.

Mi válthatta ki ezeket a decentralizáló hatású társadalmi, politikai és gazdasági változásokat? 781-ben Nagy Károly meghívott egy Albinus nevű angolszász egyházi férfiút, hogy udvarában tanítson. Wright (Wright 1982) rámutatott, hogy Albinus a beszélt latin nyelvben olyan standard nyelvtant és fonetikus kiejtést vezetett be, ami különbözött Észak-Frankföld lakosságának anyanyelvétől. „Korrekt” beszélt nyelvet csak úgy lehet tanítani, ha az egységes írásos kódon alapul. Miután Albinust 796-ban kinevezték a toursi Szent Márton kolostor apátjává, ez a központ egy negyedszázadon át kiemelkedő szerepet játszott az írott latin nyelv standard formájának kifejlesztésében. ${ }^{15}$ A mai Franciaország észak-nyugati részén fekvő Corbie kolostorban korábban kidolgozott tiszta és gazdaságos kisbetûs írásmódot tovább finomították és csiszolták - ennek eredménye a karoling minusculum. A betúket néhány standard összevonás kivételével egymástól különválasztva írták, a szócsoportok között pedig egy betû́ szélességénél kétszerte nagyobb méretû́ helyeket hagytak ki (Saenger 1999:449). A mondatokat antik típusú nagybetûvel kezdték és ponttal zárták le. A betúk kompakt mérete ugyanakkor lehetővé tette az íródeákok számára, hogy gyorsan írjanak, több szót elhelyezve a drága pergamen egy-egy lapján, mint amennyi a félig nagybetûs unciális írásmóddal* addig lehetséges volt.

15. Albinus hozzájárulását a latin nyelv írásos formáinak standardizálásához Wright tárgyalja részletesebben (Wright 1982:114,115).

* A német-római császárság alaptörvénye. - A ford.

* Az i. sz. 4-8. században a görög és latin nyelvủ kéziratokban használatos gömbölyített nagybetûs írás, a könyvírás elődje. $-A$ ford. 
A standardizált írásmód hatására csökkentek az információ oly módon való tárolásának állandó költségei, hogy az információ ismételten, akár egymást követő korszakokban is pontosan visszanyerhetô legyen. Ennek eredményeként hatalmas lendületet vett a másolatok készítése: nemcsak a Biblia, hanem más vallási szövegek és világi jellegû írások reprodukálására is sor került, elsősorban a kolostori könyvtárak számára. A Karoling birodalomból a kilencedik századtól kezdve több mint hétezer kézirat maradt fenn, ami az előző század első felétől számított évtizedenkénti produkcióhoz képest hétszázszoros növekedést jelent (McKitterick 1994:221, 235).

Az írástudók számának növekedésével a kilencedik és tizedik század során az újlatin nyelveket beszélő régiókban lehetôvé vált, hogy a Karoling udvar alapvetô vonásait - az adóbegyújtési rendszert, az igazságszolgáltatást és a katonai létesítmények ellátását - lemásolják egyre inkább decentralizált szinteken is. Az 1020-as években Frankföld északi részén jelentek meg elôször olyan dokumentumok, amelyek az emberek három társadalmi rendjét említik, nevezetesen azokét, akik imádkoznak, azokét, akik harcolnak és azokét, akik dolgoznak (Duby 1978:15). A Rajnától keletre fekvő germán területeken is végbement ugyanez a decentralizálódási folyamat, de körülbelül egy évszázadnyi késéssel. Csak a tizenegyedik század utolsó évtizedeiben került sor arra, hogy a király és a nemesség egyszerû struktúráját felváltotta a hatalom bonyolult, lépcsôzetes lebontása a hercegektől a grófokig, a ministeriales-ig és az egyszerű lovagokig (Barraclough 1984:138).

Stock (Stock 1983:14-18) leírja a latin nyelvú írástudás növekedésének társadalmi hatását Nyugat-Európában. Ahogy az írást fokozatosan elkezdték nem-liturgikus célokra használni, a szóbeli kommunikáció is egyre inkább az írott szövegekre támaszkodott - az emberi memória helyett. Stock rámutat, hogy a tizenegyedik század korai évtizedeiben az észak-itáliai városokban megjelentek a iudex-nek nevezett új típusú tisztviselők, akiknek az volt a dolguk, hogy a különféle egyezségeket írásos formában rögzítsék (Stock 1983:41). Ennek eredményeként alakult ki az, amit bírói döntéseken alapuló esetjognak nevezhetünk, s amibôl figyelemreméltó viták származtak, amelyeket - a törvénykódexek későbbi értelmezésének elősegítése érdekében - lejegyeztek (Gibson 1978:6). A szóbeli megegyezéseket ezután fel lehetett váltani írásbeli szerződésekkel, amelyek lehetôvé tették a feltételek bôvebb részletezését, és emellett könnyebben végrehajthatóak voltak. Valószínúleg nem véletlen egybeesés, hogy az észak-itáliai városok vezetố szerepre tettek szert az Észak-Európába irányuló szárazföldi távolsági kereskedelemben és a Földközi-tenger medencéjében folyó tengeri kereskedelemben. A kereskedelmi tranzakciókat a tizedik század közepétôl kezdve elôsegítette az arab számok használata is. ${ }^{16}$

A latin nyelvú írástudás terjedése kapcsolatba hozható az elsố írott alkotmányok megjelenésével. Angliában a tizenkettedik század második felében általános gyakorlattá vált, hogy a főúri családok és a köznemesség gyermekei latin nyelvű oktatásban részesüljenek (Clanchy 1979:196). A tizenharmadik század elején kibocsátott Magna Charta végső szövegét a bárók és London városának képviselôi fogalmazták meg. Rö-

16. Ebben az időszakban az arabról fordított tudományos és technikai jellegũ szövegekben alkalmazták először azt az eljárást, hogy minden szót nagyobb szóközzel választottak el egymástól (Saenger 1990a:451). 
viden szólva tehát nemcsak arról van szó, hogy a latin nyelvú írástudás terjedése egyértelmúen megelő́zte a kontraktuális forradalmat, hanem azt látjuk, hogy az írásos dokumentumok fontos szerepet játszottak az alkotmányos kormányzat kifejlődésében is.

Összefoglalva: az írásbeli szerzôdések elkészítésének és végrehajtásának lehetôvé tételével a latin nyelvú írástudás terjedése - úgy túnik - kulcsszerepet játszott a feudalizmus kialakulásában, a polgári jog fejlődésében, az alkotmányos kormányzat megjelenésében és azoknak a szabályoknak az alkalmazásában is, amelyek korlátozták a szabad árak mechanizmusának múködését. Az írástudás lassúbb terjedése a német és az orosz nemesség körében segíthet annak a megértésében, hogy ezekben az országokban az írásbeli szerződéses kapcsolatok miért csak késôbb jelentek meg. ${ }^{17}$

\section{Konszenzuális forradalom}

Az általános társadalmi változások második korszaka Európában a tizenhatodik században kezdôdött. A középkori egyház - sûrûn fellépố belsố megosztottsága ellenére is - gyakran képes volt megfékezni a világi uralkodóknak a hatalomért folytatott küzdelmeit, és ugyanakkor korlátok közé tudta szorítani a piac múködését. A protestáns reformáció és az általa kiváltott ellenreformáció azonban aláásta az egyéni cselekvés elé korábban állított korlátokat. A tizenhatodik és tizenhetedik század vallásháborúi Észak-Európában meggyöngítették a vallási intézmények szélesebb értelemben vett társadalmi szerepét. A kialakuló nemzetállamok közötti hadviselés helyhez kötötté vált, s ugyanakkor leomlottak az egyéni viselkedést szabályozó belsố korlátok. 1658ban például Hollandia tartománya olyan törvényt hozott, hogy az uzsora-tevékenységet folytató bankároktól nem tagadható meg az úrvacsora kiosztása (Davies 1996:518).

Ezekhez a társadalmi változásokhoz ugyanilyen mélyreható átalakulások társultak a gazdasági életben is. Braudel (Braudel 1979:30-40) leírja, hogy a tizenhetedik század folyamán a városok birtokába került piacok milyen gyorsan kinốtték azt a helyet, amit eredetileg kijelöltek számukra. Észak-Európában ebben az idôszakban került széles körú használatba a tengeri biztosítás és a kettős könyvelés, amit az itáliai városokban a középkor vége felé találtak fel. Németalföldön olyan új intézmények fejlődtek ki, mint például az egész évben múködô pénzpiacok, az értéktőzsde és a központi bankrendszer (Van der Wee 1977:346). A specializálódás növekedésével, amit ezek az előrelépések tettek lehetôvé, a holland munkaerô többsége integrálódott a piacgazdaságba (Slitcher van Bath 1982:30). Ezek a gazdasági fejlemények hamarosan átterjedtek Németalföldrôl más észak-európai országokra is.

Ebben az időszakban a kormányzás jellege is megváltozott az európai társadalomban. Annak a rendszernek a keretében, ami merkantilizmus néven vált ismertté, az állam beavatkozott a gazdasági életbe, hogy ösztönözze polgárainak kereskedelmi tevékenységét, versenytársaikét pedig ugyanakkor akadályozza. A nemzeti piacok terjeszkedésének támogatásához szükséges eszköznek tekintették a gyarmatok fejlesztését, az árucikkeket gyártó üzemek múködésének elômozdítását és a védôvámtarifák kivetését

\footnotetext{
17. Az Oroszországban használt cirill ábécét a kilencedik században ortodox misszionáriusok alkották meg, akiket Konstantinápolyból küldtek ki a keleti szlávok megtérítésére.
} 
(Davies 1996:523). A költségoldalon a hadseregre és a haditengerészetre fordított kiadások terén gyors emelkedés történt, mivel mindegyik kialakuló nemzetállam megkísérelte saját területének kiterjesztését szomszédai rovására. A bevételi oldalon - nagyrészt a gyorsan növekvô volumenú kereskedelmi tranzakciók indirekt megadóztatása révén - megnövekedett az adóbevételek aránya a nemzeti jövedelemben.

Ahogy az állam rendelkezésére álló források gyarapodtak, az uralkodó számára akár egy fejedelem, akár valamely testület gyakorolta a hatalmat - egyre fontosabbá vált, hogy biztosítsa magának az írástudó lakosság minél szélesebb körének támogatását. Annak a kérdésnek az eldöntésére, hogy ki képviseli a legjobban a közérdeket, az egyes államokon belül olyan elkeseredett küzdelmeket vívtak, mint amilyen például Németalföldön a spanyol monarchia ellen vívott nyolcvanéves háború (1566-1648), Németországban a harmincéves háború (1618-1648), Angliában pedig a polgárháború (1642-1648) és az 1688-as dicsôséges forradalom volt. Miután ez a kérdés eldôlt, a győztes csoport nagyrészt korlátozásoktól mentesen uralkodhatott (Davies 1996:578). ${ }^{18}$ Mivel mindegyik nagyobb nyelvi régióban széles körú konszenzus alakult ki a politikai és gazdasági döntések meghozatalának módszereire nézve, ezeket az átalakulásokat konszenæuális forradalomnak nevezhetjük. ${ }^{19}$

Első pillantásra kevés bizonyíték látszik arra, hogy az adott kor információs és kommunikációs technológiája közvetlen kapcsolatban állna ezekkel a kora-modern forradalmakkal. A technika történetében rendszerint a papír használatának a tizenharmadik században megindult bevezetése, majd a tizenötödik század közepén a nyomtatás feltalálása kap jelentékeny figyelmet (pl. Cardwell 1972:19-29). Ennek a két nagy találmánynak az európai társadalomra gyakorolt kezdeti hatása azonban csekély volt. Angliában például`1500-ban a férfiaknak még csak körülbelül tíz százaléka, a nốknek pedig mindössze egy százaléka volt írástudó (Cressy 1980:176). Ennek fố oka az, hogy a nyomtatás első fél évszázadában az Európában kinyomtatott összes szöveg háromnegyed része latinul, vagyis egy olyan nyelven íródott, amelyet kevesen tudtak olvasni (Steinberg 1955:81). Noha az anyanyelvú irodalom már a tizennegyedik században népszerúvé vált, ennek potenciális piacát behatárolta a standard helyesírás, nyelvtan és szókincs hiánya (Chaytor 1966:3. fejezet).

Ezeknek az újításoknak a társadalmi hatásai csak akkor kezdtek igazán érezhetôvé válni, amikor már lezajlott egy újabb standardizálási hullám. A tizenhatodik század elején - a latinul nem tudó olvasók ösztönzése végett, hogy minél többen vásároljanak anyanyelvükön írt könyveket - a szerzốk és a nyomdászok egyaránt kerülni kezdték a csak bizonyos régiókban ismeretes kifejezések és írásmódok használatát (Hirsch 1974:136). Ennek eredményeként a beszélt nyelvek nyomtatásban megjele-

18. Tilly (Tilly 1993) a Spanyolország ellen 1640-ben kitört portugáliai felkelést forradalomként határozza meg. A Zimmermann (Zimmermann 1983) által javasolt meghatározás értelmében azonban ez az elitváltás nem volt eléggé fontos ahhoz, hogy forradalmat jelentsen.

19. Franciaországban a XIV. Lajos gyermekkorában kitört Fronde felkeléseket (1648-1651) megkísérelt forradalomnak tekinthetjük. A régenshez hû erốk - elsôsorban annak a megosztottságnak tulajdoníthatóan, ami a párizsi országgyúlés (parlement) és a szakadár nemesség között létrejött - képesek voltak viszszaszerezni a hatalmat. Több mint egy évszázaddal később, XV. Lajos uralkodásának utolsó éveiben és XVI. Lajos idején hasonló feszültségek alakultak ki, de ezeket nem sikerült elnyomni. Ami Spanyolországot illeti, az 1820-as forradalom alkotmányos monarchiát hozott létre, bár ennek tényleges életbelépését a francia beavatkozás és a polgárháború 1837-ig késleltette. Oroszországban az 1905-ös forradalom szintén képviseleti intézmények létrehozásához vezetett. 
nô változatai a nyomtatási központokban beszélt nyelvi formák körül kezdtek fokozatosan standardizálódni. 1600-ra az összes könyvnek már több mint a felét az egyes régiók anyanyelvén nyomtatták ki (Hirsch 1974:132). A protestáns egyházak - mint Eisenstein (Eisenstein 1979:378-421) rávilágít - ösztönző módon járultak hozzá a világi írástudás terjedéséhez: ez segít megérteni, hogy Észak-Európában miért fejlődtek gyorsabban a kapitalista intézmények, mint Dél-Európában. ${ }^{20}$

A nyomtatás elérhetôvé válása lehetôvé tette az olyan jellegú információk gyors terjesztését, amilyenekre szükség volt ahhoz, hogy a hatalom birtokosaival szemben más koalíciók jöjjenek létre. Németalföldön a spanyol uralom elleni küzdelmek első négy évtizedében tízszeresére emelkedett az évente kibocsátott röpiratok száma (Harline 1987:3). Az angol polgárháború során és az angol köztársaság idôszakában egy londoni könyvkereskedố megkísérelt összegyújteni egy-egy példányt minden politikai kiadványból. Gyújteménye, amelyból a rojalista nyomdákban kinyomtatott röpiratok egy része hiányzott, húszezernél is több tételre rúgott (Aylmer 1986:65). 1687-ben egy pamflet, ami az anglikán egyháztól elszakadó szektás protestánsokat figyelmeztette II. Jakab ellenük irányuló terveire, három kiadást ért meg, és egyetlen év alatt húszezer példányban került forgalomba (Prall 1985:153). A politikai természetű szövegek nyomtatásában hasonló robbanás történt az 1789-es francia forradalom elốtt és a forradalom idején. Az 1780as évekre Franciaország minden nagyobb vidéki központjában már hetenként megjelenő egyoldalas hírlapokat nyomtattak; Párizsban 1777-tôl kezdve folyamatosan jelent meg a Journal de Paris címú napilap (Doyle 1989:46). Ezen kívül voltak különféle rendszertelenül megjelenô kiadványok is: az 1789 és 1792 között kinyomtatott politikai dokumentumokból majdnem tízezer példány maradt fenn mindmáig (Baecque 1989:165).

Látható tehát, hogy a kora-modern korszakban bekövetkezett társadalmi változásokat szintén megelőzte az információs és kommunikációs technológia területén egy nagy jelentőségû innováció: az anyanyelven történố nyomtatás. Ennek az újításnak az elterjedése - Németalföldrốl és Nagy-Britanniából kiindulva - lehetôvé tette az olyan tranzakciók körének kiszélesítését, amelyeket nem központi parancsoknak vagy utasításoknak engedelmeskedve, hanem szétaprózódó csereérdekek kielégítése végett kötöttek. Ugyanakkor mindegyik ország lakosságának egyre növekvố része vált képessé a politikai döntéshozatalban való részvételre. (Érdemes megjegyezni, hogy a kétoldalú kapcsolatok száma írástudó közösségben a populáció lélekszámával négyzetes arányban növekszik.) Végül, a nyomtatás feltalálása - amellett, hogy az írástudásra kifejtett hatása révén csökkentette a dekódolási költségeket - a tárolás állandó költségeihez képest csökkentette az információ többszörös másolás útján való továbbításának változó költségeit is.

20. Angliában az írástudók részaránya a felnốtt férfiak között 1600-ban elérte a körülbelül 30 százalékot (Cressy 1980:177). 1630-ban az amszterdami vôlegények 57 százaléka tudta leírni a nevét (Graff 1991:223). Franciaországban az írástudás körülbelül egy évszázaddal elmaradt Anglia mögött: csak 1700 körül érték el azt a szintet, hogy a vôlegények 30 százaléka képes volt leírni a nevét (Graff 1991:193). Spanyolországban az írástudás terjedése még egy további évszázaddal, Oroszországban pedig több mint két évszázaddal elmaradt Franciaország mögött (Cipolla 1969:115). Spanyolországban és Oroszországban a preskriptív forradalom - csakúgy, mint ahogyan a korábbi átalakulások esetében is történt - késleltetve következett be. Az 1868. évi spanyol forradalom élére állt katonatisztek a következô évben kiadott alkotmányban biztosították az általános választójogot. 1917 márciusában katonai és gazdasági nehézségek arra késztették az orosz hadsereg tisztjeit és a liberális politikusokat, hogy támogassanak egy átmeneti kormányt a cár leváltásában, ameddig - általános választójog mellett - megtörténhet egy alkotmányozó nemzetgyưlés összehívása. 


\section{Preventív forradalom}

A tizenkilencedik század második negyedében új típusú forradalmak sorozata robbant ki. 1830 júliusában, amikor X. Károly feloszlatta a törvényhozást és bevezette a sajtó cenzúráját, Párizsban nyílt lázadás tört ki. Egy újságkiadó, Louis Thiers vezetésével a középosztálybeli liberálisok rávették Lajos Fülöp orléansi herceget, hogy vegye át a trónt a hitelét vesztett királytól. Európa más részeit tekintve, Brüsszelben az augusztusi lázongások új átmeneti kormány megalakításához vezettek, amely deklarálta Belgium függetlenségét Németalföldtől, Anglia vidéki területein pedig a még ugyanazon az ôszön kitört felkelések hozzájárultak a konzervatívok bukásához, akik addig majdnem negyven éven keresztül gyakorlatilag megszakítás nélkül hatalmon voltak. A rákövetkező évben még általánosabbá vált forrongások után a Lord Grey vezetésével alakult liberális kormánynak 1832-ben sikerült hatályba léptetnie az úgynevezett „nagy reformtörvényt”. A választójogokat mindhárom országban kiterjesztették. Tizennyolc évvel késóbb, 1848-ban - mint a bevezetésben említettük - egy újabb forradalmi felkelési hullám Franciaországból kiindulva átterjedt Közép-Európára is. Amikorra az 1850-es évek elején helyreállt a társadalmi nyugalom, ezeknek az államoknak a többségében már új alkotmányokat fogadtak el, amelyek korlátozott hatalmat biztosítottak különféle választott testületeknek. ${ }^{21}$

Ebben az idôszakban a politikai vezetốk egész Nyugat-Európában azzal igyekeztek lecsillapítani a társadalmi mozgolódásokat, hogy olyan alkotmányokat léptettek hatályba, amelyek a lakosság nagyobb részének biztosították a részvételt a politikai döntéshozatalban. Mivel a céljuk minden esetben a társadalmi rend összeomlásának megakadályozása volt, ezeket az átalakulásokat preventí forradalomként írhatjuk le. Mint a bevezetổben már rávilágítottunk, a nép által megválasztott kormányok hozzákezdtek, hogy korrigálják a piaci rendszer hatalmi pozícióban lévő szereplối által elkövetett legsúlyosabb visszaélések és túlkapások egy részét. Általánosan elfogadott szabályozások révén - például a munkaidő hosszát és a munkafeltételeket szabályozó, valamint a városi köztisztasági körülmények javítását elốró rendeletekkel - sikerült bizonyos mértékig korlátozni az addig teljesen szabadon érvényesülő árrendszer legrosszabb hatásait. Ugyanakkor visszavontak néhány korábbi kormányintézkedést (például a magas védővámtarifákra vonatkozó előírásokat), amelyek csak kisebb csoportok érdekeit szolgálták, a lakosság többi részének a rovására.

Hogyan múködött közre az információs és kommunikációs technológia ebben a harmadik forradalmi hullámban? Az információ továbbításának változó költségei a tizenötödik századtól egészen a tizennyolcadik század végéig keveset változtak. Az 1792-ben Nagy-Britanniában eladott tizenötmillió újságot olyan nyomdákban állították elő, amelyeknek a technológiája alig különbözött Gutenberg három évszázaddal korábban megalkotott nyomdájáétól (Cranfield 1978:139). A tizenkilencedik század elsố felében azonban az új találmányok egész sora egyenletesen lefelé szorította az információ reprodukálásának költségeit.

${ }^{21}$ Spanyolországban és Oroszországban - a korábbi átalakulásokhoz hasonlóan - a preventív forradalom is késóbbre tolódott. Az 1868. évi spanyol forradalmat vezető katonatisztek a rákövetkező évben kibocsátott alkotmányban biztosították az általános szavazati jogot. Az orosz hadsereg tisztjeit és a liberális orosz politikusokat az 1917 márciusában katonai és gazdasági téren egyaránt bekövetkezett hanyatlás késztette arra, hogy egy ideiglenes kormányt támogassanak, amely az alkotmányozó nemzetgyúlés általános választójog mellett történố megválasztásáig felváltja a cári kormányzást. 
1800 körül a Lord Stanhope által kifejlesztett fém gyorssajtó használatával egyetlen nyomdász óránként már hatszáz oldalt tudott kinyomtatni - ez kétszer anynyi volt, mint a korábbi maximális teljesítmény (Bellanger 1969:(1):18). 1814-ben a londoni The Times címú napilapnál Friedrich König újítása nyomán üzembe helyeztek egy gốzmeghajtású, hengeres gyorssajtót, ami - megháromszorozva a termelést óránként kétezer oldal előállítására volt képes (Bellanger, 1969:(2):15). A következő évtizedekben a rotációs nyomda és a betűöntés fejlődése tovább növelte a gépesített nyomtatás hatékonyságát. 1848-ig a napilapok összesített példányszáma Nagy-Britanniában majdnem 80 millióra emelkedett.

Az új, gőzmeghajtású nyomdagépeket hamarosan átvették az európai kontinensen múködő nyomdák is. 1846-ban Párizsban már 23 napilap jelent meg, amelyek közül a legnagyobb, a Le Siècle elérte a 30 ezres példányszámot (Bellanger et al. 1969:146). A sajtó ideális eszköznek bizonyult többek között egy bankett-sorozat népszerûsítésére, amit 1847-ben és 1848-ban az ellenzék szervezett. Amikor az 1848. február 22-re tervezett nagy bankett megrendezését a kormány intézkedésére betiltották, az ellenzéki lapok a nemzeti gárda beavatkozását kérték (Bellanger et al. 1969:143-144). A júliusi monarchia megbuktatásához elegendő volt annyi, hogy a gárdisták összebarátkoztak azokkal, akik barikádokat állítottak fel az utcákon. Ugyanennek az évnek az ôszén azonban a sajtó legnagyobb része már ismét a rend és a stabilitás visszatérését sürgette, támogatva az annak érdekében folyó kampányt, hogy a második köztársaság alkotmánya szerinti új rendben az elsố elnök III. Napóleon legyen, aki el is nyerte a szavazatok 75 százalékát. Három évvel késôbb a legtöbb újság támogatta egy olyan alkotmány-kiegészítés iránti igényét, ami lehetôvé tette volna számára, hogy másodszorra is megválasszák. Amikor ezt az igényt elutasították, a legtöbb újság - aktívan támogató vagy passzívan elfogadó módon - felsorakozott az 1851 decemberében végrehajtott államcsíny mellett (Bellanger et al. 1969:222-248).

Látható tehát, hogy a tizenkilencedik század preventív jellegû forradalmait egy olyan innovációs hullám előzte meg, ami a tárolás állandó költségeihez képest leszorította az információ reprodukálásának és továbbításának változó költségeit. Ezek a változások kedvezôen hatottak a társadalmi döntéshozatal részleges újracentralizálódására, melynek bekövetkeztével az egyéni cselekvés korlátozására szolgáló új szabályokat már a lakosság többsége által megválasztott képviselők határozták meg. ${ }^{22}$

\section{Preskriptív forradalom}

A huszadik század elején az egyes országokon belül a társadalom valamelyik rétegét képviselő tömegpártok kialakulása együtt járt az állami szervek hatalmának növekedésével. A politikai életben már az 1880-as évek során új dimenzió alakult ki, amikor Bismarck - arra törekedve, hogy biztosítsa az állam iránti lojalitást a német dolgozók körében - kötelezővé tette a betegség-, baleset- és nyugdijbiztosítást. Franciaországban a baloldali és a közép-pártok koalíciója 1905-ben önkéntes munkanélküliségi biztosítást vezetett be. Az

\footnotetext{
22. A hálózati hatásokat tekintve az írástudási arányok ebben az idôszakban lassan változtak, miközben a társadalom vagyoni rétegeződése elkezdte lebontani azt a konszenzust, amit a nemzeti nyelvek régióin belül a megelốzô periódusban elértek (Craig 1989:151).
} 
Egyesült Királyságban Loyd George liberális kormánya hatályba léptette az 1911. évi társadalombiztosítási törvényt, ami szintén kötelezô társadalom- és egészségbiztosítást írt elố (Flora-Alber 1982:59). Oroszországban az 1917-es novemberi forradalom - a világon elsóként - monopolisztikus politikai hatalmat juttatott az egyik ilyen tömegpárt kezébe. A második világháborút közvetlenül megelőzố idôszakban egypártrendszerek jutottak hatalomra Olaszországban, Németországban, Spanyolországban és sok kisebb országban is.

A gazdaságban a források allokációját szabályozó árrendszer funkcióit - a vállalatok skálájának szélesedésével párhuzamosan - szintén egyre inkább a hatalmi hierarchiák különbözố szintjeirôl kibocsátott utasítások vették át. Egy kortárs megfigyelô, Paul Lindberg például így jellemezte az 1880-as évek végének Berlinjét: „Ha egy gyors pillantást vetünk Berlinben a kereskedelemre és az iparra, megdöbbenünk a legtöbb vállalat gigantikus méreteitôl. ... Ezek a 'modern küklopsz-múhelyek' elégítik ki a kereslet nagy részét mind Németországban, mind külföldön." (Raff 1988:178). Az ilyen „gigantikus” vállalatok egyik fontos előnye - Európában csakúgy, mint az Egyesült Államokban - az volt, hogy képesek voltak befogadni és felhasználni a tudományos kutatás eredményeit (Inkster 1991:113).

A politikai intézmények nagyobb változásainak ebben az utolsó sorozatában az embereknek azt kellett megérniük, hogy a nagy szervezetek - a politikai tömegpártok, az állami szervek és a nagyvállalatok - egyre növekvő szerepet játszanak az életükben, miközben a család és a közösségi csoportok háttérbe szorulnak. Ahhoz, hogy támogatást és védelmet biztosítsanak saját maguk számára, az egyes polgároknak csak alá kellett vetniük magukat a pártvezetôk, kormánytisztviselő́k vagy vállalati vezetốk által kibocsátott direktíváknak. Az átalakulásoknak ezt a negyedik csoportját ilyen értelemben preskriptiv forradalomnak nevezhetjük.

A társadalmi változásokat megint csak megelôzte egy egész sor új információs és kommunikációs technológiai eljárás elterjedése. 1850 után bevezettek egy olyan technológiát, ami lehetôvé tette a papírgyártást vegyi úton kezelt pépes facellulóz felhasználásával (Magee 1997). A nyomtatás és a betûszedés hatékonyságát tovább növelte a rotációs nyomdagépek, a tömöntés (sztereotípia), a sorszedő gép és a villanymotor feltalálása. 1850 és 1900 között vasúti és telegráfvonalak hálózatai épültek ki egész Európában; 1866-ban befejeződött az elsố állandóan múködő transz-atlanti kábel lefektetése. Ezek az innovációk a tárolás állandó költségeihez képest tovább csökkentették az információ átvitelének változó költségeit, s ezáltal elősegítették a centralizálódást. A híreket immár szinte pillanatok alatt össze lehetett gyưjteni a világ négy sarkából, és néhány órán belül el is lehetett juttatni azokat az emberek nagy tömegeihez. ${ }^{23}$

23. A tizenkilencedik század végén az angol Daily Mail címû újságból naponta egymillió példány fogyott, egy példány ára fél penny volt. Más nagyobb európai városokban is általában százezer fölötti példányszámban jelentek meg napilapok. 
Vegyük szemügyre most a hálózati hatások viszonylagos fontosságában bekövetkezett változások kérdését. Az 1850 és 1914 közötti időszakban Európában mindenütt végbement a közoktatás széles körủ kiterjesztése. Az első világháború idején Nyugat-Európa lakosságának már több mint kilencven százaléka tudott írni-olvasni (Graff 1991:378). Az nyitott kérdés, hogy az új írni-olvasni tudó rétegek mekkora hányada tudta ezt a képességét aktívan felhasználni írásos információk megszerzésére és azok megosztására másokkal. Angliában például a munkásosztály mindennapi életében az írni-olvasni tudás továbbra is csak csekély szerepet játszott (Graff 1991:332, 333). A társadalmat megosztó válaszfalak és véleménykülönbségek az idő elôrehaladtával minden országban egyre fontosabbá váltak (Craig 1989:242-243).

Az európai történelem 950-tôl 1950-ig tartó évezrede során bizonyos korszakokra koncentrálódó gyors társadalmi változásoknak ez a rövid áttekintése világosan mutatja, hogy azokat a mélyreható átalakulásokat, amelyeket az előzố fejezetben írtunk le, az információs és kommunikációs technológia területén minden esetben nagy jelentőségú találmányok vagy újítások bevezetése előzte meg. A technológiai innovációk jellege és az intézményrendszerben bekövetkezett változások típusa között világosan látható kapcsolat állt fenn.

\section{INFORMÁCIÓS TECHNOLÓGIA ÉS TÁRSADALMI STRUKTÚRA}

A társadalom szervezésére felhasznált információt a bevezetésben allokatí információként definiáltuk. Ennek egyik alapvetố jellegzetessége az, hogy nem additív természetû, vagyis ha további személyek is hozzájutnak és felhasználják, ez általában nem csökkenti a többiek rendelkezésére álló mennyiséget. Az ilyen információnak azonban - mint az elsố részben jeleztük - van három további olyan tulajdonsága, ami megkülönbözteti a klasszikus értelemben vett közjavaktól (például a honvédelemtốl): az allokatív információ raktározható, továbbítható és kódolás útján átalakítható. ${ }^{24}$ Ezeknek a jellegzetességeknek a társadalmi változásokra kiható következményei, amelyeket a második részben írtunk le, formálisan elemezhetők egy olyan modell adaptálásával, amit Heckathorn (Heckathorn 1996) dolgozott ki a közjavak előállításának tanulmányozására. Legyen $V$ az allokatív információ egy egységének az értéke (hétköznapi értelemben), $Q$ az előállított egységek száma, $K$ az a „költség”, amit egy személy ráfordít az információ előállításában, tárolásában, továbbításában és dekódolásában való közremúködésre, $n$ pedig azoknak a csoporttagoknak a száma, akik részt vesznek az adott közjó finanszírozásában. Egy társadalom így az egyének közötti bináris kölcsönhatások olyan halmazaként modellezhetô, ahol az egymással kölcsönhatásba lépô szereplôk kölcsönhatásának koordinációjához páronként szükséges információ optimális mennyiségét önkényesen 1-gyel egyenlônek választjuk. A kölcsönhatások minden egyes halmaza nem-kooperatív természetú játszmákból tevődik össze, amelyeket ismételten (de bizonytalan számú alkalommal) játszanak le.

\footnotetext{
24. Ezeknek a jellemvonásoknak a variációi átalakíthatják az információ természetét. Amikor a dekódolási és tárolási költségek alacsonyak, az információ egyértelmû́en közjónak tekinthetô. Amikor azonban a kódolási költségek (alacsony tárolási költségek mellett) magasak, lehetôvé válik, hogy egyeseket kizárjanak a fogyasztásból. Ez utóbbi esetben az információnak olyan tulajdonságai vannak, mint a Buchananféle (Buchanan 1965) „klubjavaknak”. Amikor mind a tárolási, mind a dekódolási költségek magasak, az információk többnyire magánjavakká válnak.
} 


\section{Az allokatív információ előállításának háromféle konfigurációja}

Vizsgáljunk meg először egy olyan, allokatív információ előállítására szolgáló rendszert, amelyben a tárolás állandó költségei a továbbítás változó költségeihez képest elhanyagolhatók, ez utóbbiak értéke pedig legyen 1. Tételezzük fel, hogy a dekódolási költségek elegendően magasak ahhoz, hogy a hálózati környezet elhanyagolható legyen. Egy ilyen rendszert egyszerúsített formában a következô egyenlettel írhatunk le:

$$
Q=n(1)
$$

Ha az ilyen információ előállításának finanszírozásához senki sem járul hozzá, akkor a termelés értéke 0 , ha viszont mindenki részt vesz benne, akkor a termelés értéke 1 lesz. E között a két szélsố érték között az információ outputja egyenes arányban növekszik a közremúködő csoporttagok számával. Az első ábra $n$ értékeit a vízszintes, $Q$ értékét pedig a függóleges tengely mentén tüneti fel. A fentebb leírt technológiát egy egyenes vonal reprezentálja, ami átlósan fut keresztül a diagramon, jelezve, hogy a centralizálódás irányában nincs előrelépés. Ennek egy példája lehet egy kö1. ábra:

Közjavak elóállítása háromféle információs technológia esetében

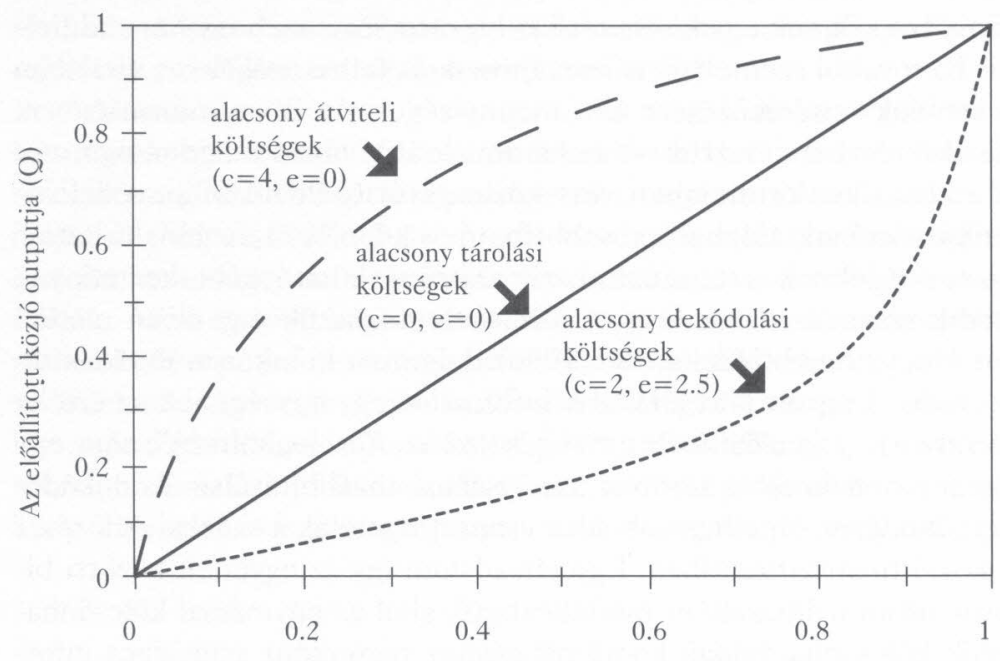

A csoport közremúködố tagjainak száma, a teljes létszámhoz viszonyítva (n)

zépkori kolostor másolóterme, ahonnan standard latin nyelven kommunikálva segítséget kérnek egy másik hasonló intézménytől, hogy a rossz termés miatt fellépő ellátási gondok következtében a szerzetesek ne szenvedjenek szükséget. Ebben az esetben az elküldött üzenet legfontosabb tartalmát az osztozkodás javasolt szabályai jelentenék (esetleg jövőbeli viszont-segítség kilátásba helyezése, hasonló körülmények esetére). 
Tekintsünk ezután egy olyan információs rendszert, amelyben az állandó tárolási költségek a változó átviteli költségekhez képest magasak. Az információ előállításához szükséges állandó költségek viszonylagos fontosságát (formális szóhasználattal: relatív súlyát) fejezzük ki a $c$ paraméterrel. ${ }^{25} \mathrm{Az}$ információ mennyisége $c$-nek csökkenô, $n$-nek pedig növekvô függvénye lesz. Az összefüggés normalizálása végett szorozzuk be az egyenlet mindkét oldalát $(c+1)$-gyel.

$$
Q=(c+1) \frac{1}{c+1 / n}
$$

Megjegyzendő, hogy ha $c=0$, a (2) egyenlet az (1) egyenletre egyszerúsödik. Ha senki sem múködik közre, a termelés értéke ekkor is 0 , ha pedig valamennyien részt vesznek az információ előállításában, a termelés értéke 1 lesz. A rögzített költségek miatt azonban az adott közjó előállítása most a részvételi arányt mutató $n$ csökkenô (konkáv) függvénye. A felsố görbe az első ábrán - a nagy volumenû termelés gazdasági elő́nyeit illusztrálva - abban az esetben ábrázolja ezt a függvényt, amikor $c=$ 4. Erre jó példa lehet egy szovjet tervezô, aki az első ötéves terv idején, az 1920-as évek végén Moszkvából táviratokat küld az országban szétszórtan elhelyezkedô üzemvezetốknek. Mivel ez a technológia a centralizációnak kedvez, az üzenet tartalma valamilyen utasításban jelenne meg, például az elérendő termelési célokra vonatkozóan.

Végül, az információ dekódolásának költsége a változó átviteli költségekhez képest legyen alacsony. Minden felhasználó, aki újonnan bekapcsolódik ennek a kommunikációs eszköznek a használatába, átad bizonyos hasznot azoknak, akik már használják az eszközt, mivel most már ez utóbbiak között is mindenki kommunikálhat egy további partnerral. A hálózati hatásokat jelöljük en-nel, ahol $e$ egy pozitív konstans. Ezek a hatások ellensúlyozzák az állandó költségek $c$ paraméterét az elôzô egyenletból. Az egyenlet mindkét oldalát $(c+1-\ell)$-vel megszorozva a termelési függvény következő, normalizált alakját kapjuk:

$$
Q=(c+1-e) \frac{1}{c+1 / n-e n}
$$

Ha $e$ (a hálózati hatás paramétere) egyenlő 0-val, a (3) egyenlet a (2) egyenlet alakját veszi fel. A termelés értéke - mint a két előzô függvény esetében is - 0 , ha senki sem múködik közre, és 1 , ha mindenki közremúködik. Ha $\ell$ értéke elegendően nagy, a hálózati hatások túlkompenzálják az állandó költségeket és a termelési függvény $n$-re nézve konvex. Mint az 1 . ábra alsó görbéje mutatja, a termelési függvény most inkább növekvố lesz, mintsem lineáris vagy csökkenô. Erre az esetre példának vehetjük a piaci információk terjesztését a tizenhetedik század elején amszterdami

25. Heckathorn (Heckathorn 1996) értelmezésében a közjavak termelési függvényének alakját egyetlen paraméter határozza meg. A jelen tanulmányban - az információ speciális jellegzetességének megragadása érdekében - a termelési függvény alakját két paramétertôl tettük függôvé. A (2) egyenlet szerint, ha $n$ $>0,5$, akkor minél nagyobb az állandó költségek $c$ paramétere, annál kisebb a további információs output, ami a finanszírozásban való nagyobb részvételból adódik (a termelési függvény homorúbbá válik). A (3) egyenletben az állandó költségeknek ezeket a hatásait kiegyenlíti a külsô környezet $e$ paramétere. Magasabb szintû̉ részvétel esetén minél nagyobb az e értéke, annál nagyobb a növekvô részvételbốl fakadóan hozzáadódó output (a termelési függvény domborúbbá válik). 
kereskedők egy csoportjának tagjai között, akik tudnak holland nyelven írni és olvasni. Az üzenetek tartalmát fóleg árak, mennyiségek és dátumok képeznék. Ahogy az írni-olvasni tudó kereskedők száma növekszik, egyre bővülnek a komplex tranzakciók lehetőségei, amelyek haszonnal járnak valamennyi résztvevő számára. Ilyen tranzakciók lehetnek például raktárról azonnal intézhetô, illetve a jövőre vállalt határidős ügyletek, külföldi váltók elfogadásával járó üzletkötések stb. (deVries-van der Woude 1997:147-154, 170).

\section{Három társadalmi kölcsönhatási játszma}

Kölcsönhatásaikon keresztül egy társadalom tagjai meghatározzák nemcsak az allokációs rendszer típusát, hanem azt is, hogy ki viseli annak fenntartási költségeit. Mint Heckathorn (Heckathorn 1996) kimutatta, a közjavak - esetünkben az információ - előállításának három lehetséges szintje van, a játékosok pedig közremúködésük négyféle szintû „kifizetődésére” számíthatnak. Ha mindkét játékos közremúködik, $n$ $=1$ és a (3) egyenlet szerint az információtermelés értéke 1 . Mindegyik játékos a ,jutalom" (Reward - R) fizetséget kapja:

$$
R=V-K
$$

A játéknak az 1. táblázatban bemutatott normál formájában ez a „fizetség” megfelel annak az outputnak, ami akkor jön létre, ha mindkét játékos az együttmúködés stratégiáját választja.

1. táblázat

Az 1. sz. játékos fizetségeinek mátrixa

\begin{tabular}{l|l|l|}
\multirow{2}{*}{ 1. sz. játékos stratégiája } & A 2. sz. játékos stratégiája \\
\cline { 2 - 3 } Együttmüködés & Együttmúködés & Cserbenhagyás \\
\hline CJutalom” $(R): V-K$ & "Balek” $(S):$ \\
& & $V \frac{(c+1-e) / 2}{c / 2+1-e / 4}-K$ \\
\hline & "Kísértés” $(T):$ & „Büntetés” $(P): 0$ \\
& $V \frac{(c+1-e) / 2}{c / 2+1-e / 4}$ & \\
\hline
\end{tabular}


Ha az egyik játékos elpártol, miközben a másik együttmúködik, akkor $n=1 / 2$ és a (3) egyenletból a termelés értéke a következóképpen adódik:

$$
\frac{(c+1-e) / 2}{c / 2+1-e / 4}
$$

Ha az 1-es számú játékos az, aki elpártolt, ô a „kísértés” (Temptation - T) fizetséget kapja:

$$
T=V \frac{(c+1-e) / 2}{c / 2+1-e / 4}
$$

Ha a 2-es számú játékos pártolt el, az 1-es számú játékos a „balek” (Sucker - S) fizetségét kapja:

$$
S=V \frac{(c+1-e) / 2}{c / 2+1-e / 4}-K
$$

Végül, ha mindkét játékos megszökik, akkor $n=0$ és az információtermelés értéke a (3) egyenletből megint csak 0. A társadalmi összeomlás ilyen esetében mindkét játékos a „büntetés” (Punishment $-P$ ) fizetségét kapja: $P=0$.

Mint köztudott, ennek a játéknak a jellegét a négyféle fizetség relatív rangsorolása határozza meg. Az érdekes elem ebben az, hogy a rangsorolás az információs és kommunikációs technológia jellegétôl függ. Az (1) egyenlettel jelzett technológia esetében az állandó költségek és a hálózati hatások egyaránt 0 -val egyenlők ( $c=\ell=$ 0 ), és a termelés a részvétel lineáris függvénye. Például, ha az adott közjó értéke $V=$ 6 és a részvételi költség $K=4$, a „balek” fizetsége kisebb, mint a „büntetés” $(P>$ $S)$ és a „kísértés” fizetsége nagyobb, mint a ,jutalom” $(T>R)$. Ennek eredményeként - ha csak egy játszmát játszanak - mindkét játékosnak az állna érdekében, hogy megszökjön, tekintet nélkül a másiknak a stratégiájára. Ismételt játszmák esetében azonban az a veszély, hogy visszautasítják az együttmúködést egy olyan játékossal, aki korábban megszökött (mint például a „szemet-szemért” vagy „szeget-szeggel” elnevezésű közismert játszma esetében), elegendô lesz ahhoz, hogy együttmúködést váltson ki. Ezt a játékot hívják „a fogoly dilemmájának”, amit a 2. táblázat középső (b) táblája mutat be. Ilyen típusú kölcsönhatások jellemzők Hirshleifer (Hirschleifer 1980) közösségi-osztozkodó társadalomtípusára.

2. táblázat

Példák az információ-előállítás háromféle játszmájára

\begin{tabular}{l|l|l|}
\multirow{2}{*}{ Az 1. sz. játékos stratégiája } & \multicolumn{2}{|c|}{ A 2. sz. játékos stratégiája } \\
\cline { 2 - 3 } & Együttmüködés & Cserbenhagyás \\
\hline Együttmüködés & $(2,2)$ & $(\underline{1,5})$ \\
\hline Cserbenhagyás & $(\underline{5,1})$ & $(0,0)$ \\
\hline
\end{tabular}


(a) a „csirkék" játszmája $(c=4, e=0)$

\begin{tabular}{l|l|l|}
\multirow{2}{*}{ Az 1. sz. játékos stratégiája } & A 2. sz. játékos stratégiája \\
\cline { 2 - 3 } & Együttmúködés & Cserbenhagyás \\
\hline Együttmúködés & $(2,2)$ & $(-1,3)$ \\
\hline Cserbenhagyás & $(3,-1)$ & $(\underline{0,0})$ \\
\hline
\end{tabular}

(b) „a fogoly dilemmája” ( $c=0, \ell=0$ )

\begin{tabular}{l|l|l|}
\multirow{2}{*}{ Az 1. sz. játékos stratégiája } & A 2. sz. játékos stratégiája \\
\cline { 2 - 3 } & Együttmüködés & Cserbenhagyás \\
\hline Együttmúködés & $(\underline{2,2})$ & $(-3,1)$ \\
\hline Cserbenhagyás & $(1,-3)$ & $(\underline{0,0})$ \\
\hline
\end{tabular}

(c) biztonsági játszma ( $c=2, e=2,5)$

$V=6, K=4$

A Nash-egyensúlyokat aláhúzás jelzi.

Vizsgáljunk meg ezután egy olyan kommunikációs technológiát, amelynél az átvitel állandó költségei fontosak $(c>0)$. Ha egyszer ezeket az állandó költségeket fedezték és ebből adódóan sikerült elérni a nagy tömegú termelés gazdasági előnyeit, többé nem jár nyereséggel, ha további résztvevôk kapcsolódnak be a termelésbe. Ennek eredményeként a „balek” fizetsége nagyobb, mint a "büntetés” $(S>P)$. Ekkor a „csirkék" játszmáját kapjuk, amit a 2. táblázat felsố (a) táblája mutat be. Itt, ha az egyik játékos már úgy döntött, hogy megszökik, akkor a másiknak az együttmúködés áll érdekében. Ez a struktúra Hirshleifer (Hirschleifer 1980) dominanciára épülő társadalomtípusára jellemző. A technológia egy harmadik típusában további résztvevők részérôl erôs hálózati hatások vannak jelen $(e>0)$. A termelési függvény gyorsított növekedést mutató formája miatt jelentékeny veszteség mutatkozik a termelésben, ha az egyik játékos a szökést választja. Ennek eredményeként a „kísértés” fizetsége kisebb lesz a ,jutalomnál” $(T<R)$. Egyik játékos sincs ösztönözve arra, hogy meneküljön a „,büntetéstốl”. Ha azonban mindegyik bizakodik abban, hogy a másik együttmúködik, akkor mindketten az együttmúködő megoldást választják. Ez az úgynevezett „,biztonsági játszma”, amit a 2. táblázat alsó (c) táblája mutat. Eltérôen „a fogoly dilemmájától”, itt egyik játékos sem érez kísértést arra, hogy eltérjen az együttmúködő megoldástól. Az ilyen kényszer nélküli együttműködés a hatékonyság biztosítása érdekében alapvetốen jellemzố a társulási hajlam Hirshleifer-féle (Hirschleifer 1980) harmadik típusára, ami a szabadon eladható és megvásárolható tulajdonjogokon alapul.

\section{A forradalom dinamikája}

A „biztonsági játszmának” és „a fogoly dilemmájának” az esetében az egyének párosítása véletlenszerú lehet, míg a „csirkék” játszmájában feltételezhetô, hogy nagyobb számú alárendelődésre hajlamos játékos egymástól függetlenül külön-külön lép kölcsönhatásba egyetlen domináns játékossal. Noha ez a bináris szintre lebontott mo- 
dell nem tudja pontosan megmagyarázni azokat a folyamatokat, amelyek egy társadalmat valamely egyensúlyi állapottól eljuttatnak egy másik egyensúlyig, mindazonáltal felhasználható a társadalmi struktúrák alapvető formáinak a jellemzésére, illetve azoknak a körülményeknek a leírására, amelyeknek a fennállása esetén ezek összeomlanak. $^{26}$

Az információs és kommunikációs technológia területén bevezetett újítások a négyféle fizetség rangsorának megváltoztatásával befolyásolják a társadalmi kölcsönhatások természetét. A 2. ábra az allokatív információ előállításának állandó és változó költségei közötti arányt $(c)$ a vízszintes tengelyen, míg a hálózati hatásoknak a változó költségekhez viszonyított arányát $(e)$ a függő́leges tengelyen tünteti fel. A 2. táblázatból a „csirkék” játszmája $(C)$, „a fogoly dilemmája” $(P)$ és a „biztonsági játszma” ( $A$ ) az ábrán a $C$, a $P$, illetve az $A$ pontokban jelenik meg. A ,csirkék” játszmája és „a fogoly dilemmája” közötti különbségtétel a „balek” és a „büntetés” fizetségeinek egymáshoz viszonyított értékeitôl függ. Tekintsük $c$ és $\ell$ olyan értékeit, amelyekre $S$ $=P$. Az 1. táblázatból a következô egyenletet kapjuk:

$$
V \frac{(c+1-e) / 2}{c / 2+1-e / 4}-K=0
$$

Legyen $k=K / V$.

$(1-k) c-(1-k / 2) e-(2 k-1)=0(5)$

Ezt az egyenletet a 2. ábrán a $S=P$ határvonal ábrázolja. Ettôl a vonaltól jobbra az állandó költségek elég magasak ahhoz, hogy a „csirkék” játszmájára kerüljön sor $(S>P)$; a vonaltól balra pedig ezek eléggé elhanyagolhatók ahhoz, hogy „a fogoly dilemmája" $(S<P)$ játszódjon le.

\footnotetext{
26. Tegyük fel például, hogy $B$ és $C$ egymástól függetlenül a „csirkék” játszmáját játsszák $A$-val, aki a domináns szereplổ mindkét viszonylatban. Tekintsük azt az esetet, ha $B$ és $C$ olyan koalíciót alkot $A$ megbuktatására, amelyben $B$ lenne az új domináns játékos. Mindaddig, amíg a 2. táblázat (a) táblája szerinti „fizetségek" továbbra is fennállnak, $C$-nek nem lenne semmi nyeresége. Ennek eredményeként a kezdeti egyensúly továbbra is fenntartható maradna. Ha azonban a „balek” fizetsége a „büntetés” szintje alá csökken, a helyzet drasztikusan megváltozik. Ekkor $B$ és $C$ egyaránt ösztönözve van arra, hogy $A$-hoz való viszonyukban egyidejûleg a cserbenhagyás stratégiáját válasszák. Továbbá - feltéve, hogy módjukban áll megbüntetni a cserbenhagyást $-B$ és $C$ között most megvalósulhat az együttmúködés.
} 
2. ábra

Információs technológia és a társadalmi kölcsönhatások játszmái

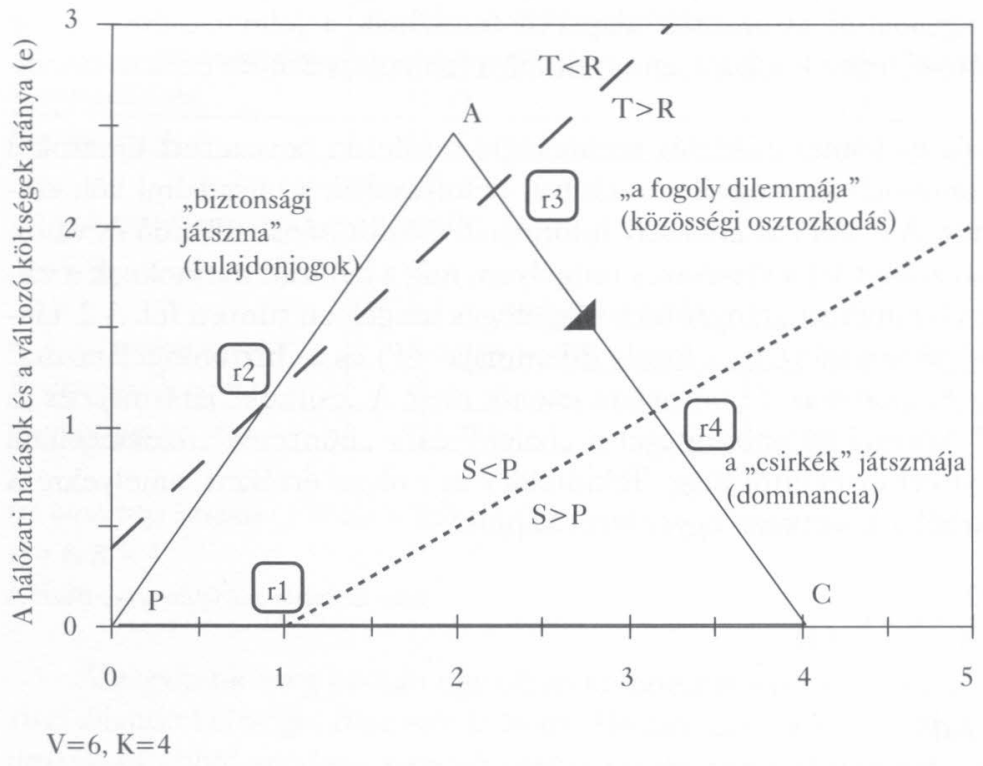

Az állandó és a változó költségek aránya (c)

Azt, hogy az adott esetben a játszma „a fogoly dilemmájának” vagy a „biztonsági játszmának” fog megfelelni, a „kísértés” és a „jutalom” fizetségek egymáshoz viszonyított értékei határozzák meg. Az 1. táblázatból $c$ és $e$ olyan értékei, amelyekre nézve $T=R$, a következóképpen adódnak:

$$
k c-(1 / 2+k / 2) e+2 k-1=0(6)
$$

A 2. ábrán ez az egyenlet megfelel a $T=R$ vonalnak. E fölött a határvonal fölött a hálózati hatások elegendốen fontosak ahhoz, hogy megszüntessék a cserbenhagyásra irányuló kísértést, mihelyt a játékosok elérték az együttmúködő megoldást. Ennélfogva tehát a „biztonsági játszma” alakul ki $(T<R)$. A határvonal alatt azonban a hálózati hatások elég csekélyek ahhoz, hogy „a fogoly dilemmája” $(T>R)$ álljon elő. ${ }^{27}$

Vizsgáljuk meg, hogy az elôző részben leírt információs és kommunikációs technológiai innovációk sorozata milyen hatással van a játékosok által választott egyensúlyi stratégiákra. Tételezzük fel, hogy a két játékos közül az egyiknek joga van elsôként eldönteni, hogy az elôzố játszma kimenetelének figyelembevételével megváltoztassa-e a stratégiáját. A továbbiakban őt tekintjük a domináns (1. számú) játékosnak, míg a másikat, aki csak az elôző után dönthet, alárendelt (2. számú) játékosnak

${ }^{27}$. Van még egy harmadik határvonal is, ami akadályozza, hogy a „kísértés” fizetsége nagyobb legyen, mint a „büntetés”. A (3) egyenlet szerinti termelési függvény esetében az az állapot jön létre, amikor $e<c+1$. 
nevezzük. ${ }^{28}$ Brams (Brams 1994) feltételezéseinek értelmében a játék akkor kezdôdik meg, amikor egyik játékos sem kívánja megváltoztatni a stratégiáját. Tegyük fel, hogy kezdetben magasak az információtárolás állandó költségei. A társadalmat ebben az esetben egy olyan pont képviselheti, mint például a $C$ pont a 2. ábrán. Mivel a „balek" 1 értékú fizetsége - a 2. táblázat (a) táblájának alsó kockáiban jelzett értékek szerint - magasabb, mint a 0 értékü „büntetés”, ha a domináns játékos a cserbenhagyást választja, akkor az alárendelt játékos együtt fog múködni. Ez a játék megfelel az olyan viszonyoknak, mint amilyenek a nyolcadik század közepén a frank nemesek és királyuk között álltak fenn, ahogy a második részben leírtuk. Mivel az információtárolás magas költségei adottak voltak, az optimális megoldás a döntéshozatal központosítása volt Kis Pipin személyében.

Tegyük fel most, hogy bevezetnek egy újítást, ami csökkenti az információfeldolgozás állandó költségeit, mint ahogyan a latin nyelv standardizálásának esetében történt a középkorban. Mivel az állandó költségeket jelölő $c$ változó értéke csökken, a társadalom bal felé mozdul el, amíg el nem éri a $r 1$ pontot, ahol keresztezi az $S=$ $P$ határvonalat. Mivel a „balek” fizetsége a „büntetés” értéke alatt van, az a játékos, aki eddig együttmúködött, kísértést fog érezni a cserbenhagyásra. A 2. táblázat (b) táblájából látható, hogy „a fogoly dilemmájának” megfelelố új játszma Nash-egyensúlya a kölcsönös cserbenhagyás. Folk teorémája szerint az együttmúködő megoldás akkor tartható fenn, amikor - végtelenül hosszú ideig tartó vagy véletlenszerúen befejeződő kölcsönhatás esetén - a jövốbeli viszonzás fenyegetése potenciális eszközként szolgál a cserbenhagyók megbüntetésére (Rasmusen 1989:91-93). ${ }^{29}$ A tizenharmadik században az angol király és a bárók ezt a játékot játszották, mindaddig ismételve, amíg végül a Magna Chartában rögzített szabályok alapján általánosan elfogadták és hatályba léptették a királyi hatalom korlátozásait (Maddicott 1994). Ez tehát megvilágítja az előző részben leírt középkori kontraktuális forradalmak esetét. Az új egyensúlyi helyzetben egy olyan pontnál, mint például a $P$ pont a 2 . ábrán, a hálózati környezet hatásai a tárolás állandó költségeihez és az átvitel változó költségeihez képest - az információ dekódolásának magas költségei miatt - alacsonyak. Ennek megfelelően tehát motiváció lép fel olyan módok keresésére, amelyek csökkentik az információ dekódolásának költségeit. Mint az anyanyelven történố nyomtatás példája mutatja, az ilyen innovációk eredménye a hálózati hatások növekedése lesz. Ha ezek a hatások eléggé erősek, a társadalom - egy olyan pontnál, mint például az $r 2$ - át fogja lépni a $T=R$ küszöböt. A „biztonsági játszmában” a 2. táblázat (c) táblájának felső kockái azt mutatják, hogy a „jutalom” értéke (2) magasabb, mint a „kísértés” fizetsége (1). Büntetésre nincs szükség többé, mivel a kölcsönös együttmúködés - ha egy-

28. Mivel az egyensúlyi fizetségek a „biztonsági játszma” és „a fogoly dilemmája” esetén szimmetrikusak, a játék menetének nincs hatása az eredményre és úgy tekinthető, hogy az akár pénzfeldobással is eldönthetô. A „csirkék” játszmájában azonban a játék menete befolyásolja a játékosok fizetségét. Fel kell tételezni, hogy az elsố stratégiaválasztás jogának odaítélésérốl a játékon kívül döntenek. A középkorban a játékosok származása és katonai képességei fontos tényezốk voltak a rangelổnyök meghatározásában. A forradalmi Oroszországban - úgy tûnik - a játékosok szónoki és röpiratírási képességei játszottak fontos szerepet.

29. A közös büntetés és a közös jutalom esetében létrejövổ egyensúlyok közötti választás analógiába állítható az információgyưjtés individualista és kollektivista stratégiái között való különbségtétellel, amit Greif (Greif 1994) modellezett, amikor a tizenegyedik századi genovai és maghrebi kereskedôket összehasonlította. Witt (Witt 1996) evolúciós keretben értelmezi az együttmúködés kialakulását. 
szer sikerült elérni - Nash-egyensúlyhoz vezet. Mindkét játékos hajlamos lesz eltérni a korábbi, „,büntetéshez” vezetô stratégiától. A „biztonsági játszma” tipikus konfigurációját az $A$ pont mutatja a 2. ábrán. A mutációnak ez a második típusa megvilágíthatja a fent leírt konszenzuális forradalom lefolyását, ami például Németalföldön a tizenhatodik század végén és a tizenhetedik század elején ment végbe. Az anyanyelven történố nyomtatás erốteljes hálózati hatásainak következtében egy olyan fốnemes, mint Orániai Vilmos, többet nyerhetett abból, hogy egy új független állam létrehozásában együttmúködött a kálvinista polgársággal, mint ha a spanyol koronához menekült volna.

Abban az esetben, ha a dekódolási és a tárolási költségek alacsonyak, nyomás jön létre az átvitel változó költségeinek csökkentésére. Mivel az innováció ebben az irányban hat, a központ és a periféria közti kommunikáció költségei a periférián folyó lokális kommunikáció költségeihez viszonyítva alacsonyabbak lesznek. Következésképpen a hálózati hatások fontossága egy bizonyos ponton elegendôen mélyre süllyed ahhoz, hogy a „kísértés” fizetségét ismét a „jutalom” értéke fölé emelje. A társadalom - az együttmúködésre ösztönzố korábbi közös érdek eltúnésével - a 2. ábra $r 3$ pontjánál felülrôl lépi át a $T=R$ határvonalat. Amikor elôször a domináns játékos, majd az alárendelt játékos is azzal fenyeget, hogy a cserbenhagyást választja, egy újabb típusú forradalmi helyzet áll elő. A társadalomnak megint csak meg kell oldania „a fogoly dilemmáját”. Egy ismételt játszmában mindkét fél együttműködése csak akkor biztosítható, ha fennáll egy olyan „büntetés” veszélye, ami elriasztja a játékosokat attól, hogy letérjenek errôl az útról. Ennek belátásával érthetővé válhatnak a tizenkilencedik század középső évtizedeiben lezajlott preventív típusú forradalmak, melyeknek a célja a teljes társadalmi összeomlás elkerülése volt. A tizenkilencedik századi Franciaországban - mint a második rész bevezetésében jeleztük - a korábbi forradalmi periódusban létrejött konszenzus azért omlott össze, mert a sajtó által támogatott erôs érdekcsoportok megkísérelték a társadalom növekvő jólétét a saját hasznukra fordítani. A válság akkor oldódott meg, amikor a földbirtokosok, a középosztály, a parasztok és sok munkás is egyetértésre jutott abban, hogy támogassák a III. Napóleon által 1852-ben hatályba léptetett új alkotmányt, mivel ez létrehozta a törvényhozás alsó kamaráját, a Corps législatif-ot, amelynek tagjait a felnốtt férfiak részére biztosított általános választójog gyakorlásával választhatták meg. Ennek hatására a domináns játékos hajlandó volt alávetni magát a rá nézve is kényszerítô erejû alkotmányos korlátozásoknak.

Amennyiben a további innovációk az információ-átvitel területén elég erôsek ahhoz, hogy tovább gyöngítsék a hálózati hatásokat, a társadalom eljuthat az $S=P$ határvonal alá. Forradalmi helyzet az $r 4$ pontnál áll elô, mivel a „csirkék” játszmája újból megkívánja, hogy az egyik játékos fölérendelje magát a másiknak. Ilyen módon magyarázhatók a késôi tizenkilencedik századi és korai huszadik századi preskriptív forradalmak, amelyekben az egyének hozzájárultak, hogy életük folyását kormányhivatalok és politikai tömegpártok döntései határozzák meg. A második részbốl erre nyújt példát az oroszok többségének hajlandósága arra, hogy az 1917. évi bolsevik puccsot közvetlenül követô években - az elkeserítő gazdasági viszonyok ellenére - inkább Lenint támogassák, mintsem hogy a fehérekhez meneküljenek. 
Összefoglalva az eddigieket tehát azt mondhatjuk, hogy 950-től 1950-ig a források allokációjára felhasznált információ előállításának folyamata Európában - teljes kört leírva - keresztülment a „szocialitás” Hirshleifer (Hirschleifer 1980) által leírt mindhárom formáján. Kezdetben - egy olyan információs rendszerben, ahol túlnyomóan a szóbeliség uralkodott - a hálózati hatásokhoz és a változó költségekhez képest magasak voltak az állandó költségek. Ennek megfelelóen a legtöbb játékos számára racionális döntés volt, hogy alávessék magukat egyetlen személy parancsainak. Az elsố ezredforduló elôtt azonban az írott és a beszélt latin nyelv standardizálása csökkentette az információtárolás állandó költségeit, s ezáltal ösztönzôen hatott olyan betartatható szabályok közös megegyezésen alapuló elfogadására, amelyek elősegítették az együttmúködést. 1500 után az egyes nyelvek standard formáinak a nyomtatás segítségével megvalósult széles körú terjedése a nemzeti nyelvi régiókon belül csökkentette az információ dekódolásának költségeit. Az ebból eredő hálózati hatások szükségtelenné tették az egyház, a céhek és más egyesületek támogatásával korábban létrejött „osztozkodó” jellegû́ berendezkedés szabályait. Következésképpen - a szabályok hatályon kívül helyezésével - kibôvültek a tulajdonjogok szabad áras rendszerben történő adásvételének lehetőségei. A tizenkilencedik század első felében azonban a gépesített nyomtatás elterjedése megemelte az információfeldolgozás állandó költségeit. A társadalom visszakerült a politikai konfliktusok helyzetébe, és a kölcsönös együttmúködés biztosításához ismét akár erőszakkal is betartatható szabályokra volt szükség, amelyeket ezúttal az új alkotmányok szövegében rögzítettek. A huszadik század elején az ugyanebben az irányban folytatódó további technológiai fejlődés segítségével nagyon sok embert sikerült rávenni arra, hogy alávessék magukat néhány vezetô utasításainak. A társadalom - az új technológiák kifejlődése nyomán - mindegyik esetben elérkezett egy bizonyos ponthoz, amelynél a paraméterek kis mértékú változása is elegendő volt ahhoz, hogy racionális egyéneket társadalmi kölcsönhatásaik mintáinak átrendezésére késztessen.

\section{ÖSSZEFOGLALÁS}

Ebben a tanulmányban bemutattuk, hogy az európai történelem során a társadalmi viszonyok különféle típusú átalakulásai négy fontosabb korszakra koncentrálódva mentek végbe. A középkor fénykorában a társadalom átszervezôdése írásbeli szerzôdések decentralizált használatán keresztül valósult meg - ezt neveztük kontraktuális forradalomnak. A kora-modern korszakban az egyes nemzeti nyelvek régióiban széles körü konszenzus alakult ki - ez volt a konszenzuális forradalom. A tizenkilencedik század elsố felében az uralkodó osztályok reformokat léptettek életbe a társadalmi zavarok elhárítása érdekében (például az 1848. évi események során) - ezt neveztük preventí forradalomnak. Végül, a huszadik században bizonyos tömegszervezetek az egyének számára azok számos jogáért cserébe biztonságot nyújtottak - ezt tekinthetjük preskriptív forradalomnak.

Kimutattuk, hogy mindegyik forradalmi periódus valamilyen nagyobb jelentőségú információs és kommunikációs technológiai újítás vagy találmány elterjedését követte, ami az adott korszakban megfigyelt változásokat szolgálta. A standardizált latin nyelv az információtárolás költségeinek csökkentésével elősegítette a decentralizálódást. Az anyanyelven történő nyomtatás segítségével az emberek sokasága képessé 
vált országos kommunikációs hálózatok létrehozására. A gôzmeghajtású gépekre épülố nyomdaipari technológia az átviteli költségek jelentős csökkentésével lehetôvé tette valamennyi polgár számára, hogy részt vegyenek azoknak a megoldásoknak a megtalálásában, amelyek a szabad piaci mechanizmusok felismert fogyatékosságainak a korrekcióját szolgálták. A tizenkilencedik század végén a nyomtatási költségek további drasztikus lezuhanása olyan tömegközönséget teremtett, amely később hajlandó volt egyéni jogait feláldozni a nagyobb biztonság oltárán.

Úgy tûnik, hogy ezek az innovációk oly módon váltottak ki forradalmakat, hogy a társadalom rendelkezésére álló források allokációja terén megváltoztatták az utasítások, a szabályok és az árak fontosságának egymáshoz viszonyított arányait. A kontraktuális forradalom magyarázható azokkal az újításokkal, amelyek csökkentették az információtárolás állandó költségeit, lehetôvé téve, hogy a parancsok vagy utasítások helyét kényszerítő eszközökkel betartatható szabályok vegyék át. A konszenzuális forradalom akkor következett be, amikor a külsố környezetbôl érkezố erôteljes hálózati hatásokat elősegítő technológia lehetôvé tette, hogy az elidegeníthetố tulajdonjogok árának a fontossága megnövekedjen - az önkéntesen vállalt szabályok kárára. Az állandó költségek relatív súlyát növelố további újítások egymást követô preventív és preskriptív forradalmakat váltottak ki, melyek során az ármechanizmusok érvényesülését először ismét betartatható szabályok, majd utasítások és parancsok korlátozták.

Rohonyi András forditása

IRODALOM

Aylmer, G. E. (1986): Rebellion or Revolution? England 1640-1660. Oxford University Press, Oxford

Baecque, A. de (1989): Pamflets: Libel and Political Mithology. In: R. Darnton és D. Roche (eds.) Revolution in Print: The Press in France, 1775-1800. University of California Press, Berkeley

Bannyard, M. (1995): Language and Communication in Carolingian Europe. In: R. McKitterick (ed.) The New Cambridge Medieval History, Volume II, c.700-c.900. Cambridge University Press, Cambridge

Barraclough, G. (1984): The Origins of Modern Germany. W.W. Norton, New York

Bloch, M. (1939/1994): La Société Féodale. Albin Michel, Paris

Bellanger, C., Godechout - J., Guiral, P. - Terrou, F. (1969): Histoire Générale de la Presse Française, volume II, De 1815 à 1871. Presses Universitaires de France, Paris

Borneque-Winandi, É. (1980): Napoléon III, 'empereur social'. Téqui, Paris

Brams, S.J. (1994): Theory of Moves. Cambridge University Press, Cambridge

Braudel, F. (1979): The Wheels of Commerce: Civilization and Capitalism, 15th18th Century. Harper \& Row, New York

Bresnahan, T. F. - Trajtenberg, M. (1995): General Purpose Technologies: 'Engines of Growth'?. Journal of Econometrics. 65:83-108

Buchanan, J. M. (1965): An economic theory of clubs. Economica. 32:1-14 
Cameron, R. (1993): A Concise Economic History of the World, second edition. Oxford University Press, Oxford

Cardwell, D. S. L. (1972): Technology, Science and History: A Short Study of the Major Developments in the History of Western Mechanical Technology and Their Relationships with Science and Other Forms of Knowledge. Heinemann Educational, London

Chaytor, H. J. (1945/1966): From Script to Print: An Introduction to Medieval Vernacular Literature. Sidgwick \& Jackson, London

Cipolla, C. M. (1969): Literacy and Development in the West. Penguin, Harmondworth

Glanchy M. T. (1979): From Memory to Written Record. Edward Arnold, London

Clanchy, M. T. (1983): England and Its Rulers: 1066-1272: Foreign Lordship and

National Identity. Fontana Press, London

Conlisk, J. (1996): Why Bounded Rationality?. Journal of Economic Literature. 34:669-700

Craig, G. A. (1989): Europe 1815-1914, Third Edition, Harcourt Brace Jovanovich, New York

Cranfield, G. A. (1978): The Press and Society: From Caxton to Northcliffe. Longman, New York

Gressy, D. (1980): Literacy and the Social Order: Reading and Writing in Tudor and Stuart England. Cambridge University Press, Cambridge

Davies, N. (1996): Europe: A History. Oxford University Press, Oxford

de Vries, J. - van der Woude, A. (1997): The First Modern Economy: Success, Failure and Perseverance of the Dutch Economy, 1500-1815. Cambridge University Press, Cambridge

Douglas, M. (1982): Cultural Bias. In: M. Douglas (ed.) In the Active Voice. Routledge \& Kegan Paul, London

Doyle, W. (1989): The Oxford History of the French Revolution. Oxford University Press, Oxford

Duby, G. (1978): Les trois ordres ou l'imaginaire du féodalisme. Gallimard, Paris

Dudley, L. (1995): Space, Time, Number: Harold Innis as Revolutionary Theorist. Canadian Journal of Economics. 28:754-769

Dudley, L. (1999): Communications and Economic Growth. European Economic Review. 43(3):595-619

Eisenstein, E. L. (1979): The Printing Press as an Agent of Change. Cambridge University Press, Cambridge

Flora, P. - Alber, J. (1982): Modernization, Democratization, and the Development of Welfare States in Western Europe. In: P. Flora - A. J. Heidenheimer (eds.) The Development of Welfare States in Europe and America. Transaction Books, New Brunswick, N.J.

Fouracre, P. (1995): Frankish Gaul to 814. In: R. McKitterick (ed.) The New Cambridge Medieval History, Volume II, c.700 - c.900. Cambridge University Press, Cambridge

Freeman, C. (1994): The Economics of Technical Change. Cambridge Journal of Economics. 18:463-514 
Ganshof, F. L. (1952): Feudalism. Longmans, Green and Co., London

Ganz, D. (1987): The Preconditions for Caroline Minuscule. Viator. 18:23-44

Gibson, M. (1978): Lanfranc of Bec. Clarendon Press, Oxford

Girard, L. (1986): Napoléon III. Fayard, Paris

Goldstone, J. A. (1986): Introduction: The Comparative and Historical Study of Revolutions. In: J. A. Goldstone (ed.) Revolutions. Theoretical, Comparative and Historical Studies. Harcourt Brace Jovanovich, San Diego

Goldstone, J. A. (1991): Revolution and Rebellion in the Early Modern World. University of California Press, Berkeley

Graff, H. J. (1991): The Legacies of Literacy: Continuities and Contradictions in Western Culture and Society. Indiana University Press, Bloomington, Ind.

Greif, A. (1994): Cultural Beliefs and the Organisation of Society. A Historical and Theoretical Reflection on Collectivist and Individualist Societies. Journal of Political Economy. 102:912-950

Harline, C. E. (1987): Pamphlets, Printing and Political Culture in the Early Dutch Republic. Martinus Nijhoff, Dordrecht

Heckathorn, D. (1996): Dynamics and Dilemmas of Collective Action. American Sociological Review. 61:2:250-277

Heer, F. (1975): Charlemagne and His World. Macmillan, New York

Hibbert, A.B. (1971): The Economic Policies of Towns. In: M. M. Postan, E. E. Rich és E. Miller (eds.) The Cambridge Economic History of Europe, Volume III, Economic Organization and Policies in the Middle Ages. Cambridge University Press, Cambridge

Hirsch, R. (1974): Printing, Selling and Reading, Second printing. Otto Harrassowitz, Wiesbaden

Hirshleifer, J. (1980): Privacy: Its Origin, Function and Future. The Journal of Legal Studies. 9:649-664

Holt, J. C. (1992): Magna Carta, Second Edition. Cambridge University Press, Cambridge

Inkster, I. (1991): Science and Technology in History: An Approach to Industrial Development. Macmillan, Houndsmill, Hamphshire, England

Innis, H. A. (1950): Empire and Communications. Clarendon, Oxford

Innis. H. A. (1951): The Bias of Communication. University of Toronto Press, Toronto Kuran, T. (1995): Private Truths, Public Lies: The Social Consequences of Preference Falsification. Harvard University Press, Cambridge, MA

Lipsey, R. G. - Bekar, C. - Carlaw, K. (1998): What Requires Explanation?. In: E. Helpman (ed.) General Purpose Technologies and Economic Growth. MIT Press, Cambridge, MA

Maddicott, J. R. (1994): Simon de Monfort. Cambridge University Press, Cambridge Magee, G. B. (1997): Labour, Capital and Technology in Britain and America, 1860-1914. Cambridge University Press, Cambridge

McKitterick, R. (1994): Script and Book Production. In: R. McKitterick (ed.) Carolingian Culture: Emulation and Innovation. Cambridge University Press, Cambridge 
Miquel, P. (1992): Le Second Empire. Plon, Paris

Mokyr, J. (1990): The Lever of Riches: Technological Creativity and Economic Progress. Oxford University Press, New York

North, D. C. (1990): Institutions, Institutional Change and Economic Performance. Cambridge University Press, Cambridge

Perez, C. (1985): Microeconomics, Long Waves and Word Structural Change: New Perspectives for Developing Countries. Word Development. 13:441-463

Plessis, A. (1985): The Rise and Fall of the Second Empire, 1852-1871. Cambridge University Press, Cambridge

Poly, J.-P. - Bournazel É. (1991): La mutation féodale Xe-XIIe siècle. Presses Universitaires de France, Paris

Popkin, J. (1989): Journals: The New Face of News. In: R. Darnton és D. Roche (eds.) Revolution in Print: The Press in France, 1775-1800. University of California Press, Berkeley

Prall, S. E. (1985): The Bloodless Revolution, England 1688. University of Wisconsin Press, Madison

Raff, D. (1988): A History of Germany from the Medieval Empire to the Present. Berg, Hamburg

Rasmusen, E. (1989): Games and Information: An Introduction to Game Theory. Basil Blackwell, Oxford

Russel, J. Cox (1985): The Control of Late, Ancient and Medieval Population. The American Philosophical Society, Philadelphia

Saenger, P. (1990): La naissance de la coupure et de la séparation des mots. In: H.-J. Martin és J. Vezin (eds.) Mise en page et mise en texte du liore manuscrit. Éditions du Cercle de la Librairie-Promodis, Paris

Saenger, P. (1990a): Coupure et séparation des mots sur le Continent au Moyen Âge. In: H.-J. Martin és J. Vezin (eds.) Mise en page et mise en texte du livre manuscrit. Éditions du Cercle de la Librairie-Promodis, Paris

Skocpol, T. (1979): States and Social Revolutions. Cambridge University Press, Cambridge

Slicher van Bath, B. H. (1982): The Economic Situation in the Dutch Republic during the Seventeenth Century. In: M. Aymard (ed.) Dutch Capitalism and World Capitalism. Cambridge University Press, Cambridge

Smith, V. L. (1991): Rational Choice: The Contrast Between Economics and Psychology. Journal of Political Economy. 99:877-897

Steinberg, S. H. (1955): Five Hundred Years of Printing. Penguin, Harmondsworth

Stock, B. (1983): The Implications of Literacy: Written Language and Models of Interpretation in the 11 th and 12 th Centuries. Princeton University Press, Princeton, N.J.

Taylor, A. J. P. (1980): Revolutions and Revolutionaries. Hamilton, London

Thompson, M. - Ellis, R. - Wildavsky. A. (1990): Cultural Theory. Westview Press, Boulder 
Thrupp, S. L. (1971): The Guilds. In: M. M. Postan, E. E. Rich és E. Miller (eds.) The Cambridge Economic History of Europe, Volume III, Economic Organization and Policies in the Middle Ages. Cambridge University Press, Cambridge

Tilly, C. (1993): European Revolutions, 1492-1992. Blackwell, Cambridge, Mass.

Tullock, G. (1974): The Social Dilemma: The Economics of War and Revolution. University Publications, Blacksburg, Va.

Van der Wee, H. (1977): Monetary, Credit and Banking Systems. The Cambridge Economic History of Europe, vol 5, The Economic Organization of Early Modern Europe. 290-392

Verhulst, A. (1995): Economic Organization. In: R. McKitterick (ed.) The New Cambridge Medieval History, Volume II, c.700-c.900. Cambridge University Press, Cambridge

Witt, U. (1996): Moral Norms and Rationality within Populations: An Evolutionary Theory. In: J. C. Pardo - F. Schneider (eds.) Current Issues in Public Choice. Edward Elgar, Celtenham

Wright, R. (1982): Late Latin and Early Romance in Spain and Carolingian France. Francis Cairns, Liverpool

Wright, R. (1997): Linguistic Standardization in the Middle Ages in the Iberian Peninsula: Advantages and Disadvantages. In: D. A. Trotter - S. Gregory (eds.) De mot en mot: Aspects of Medieval Linguistics. University of Wales Press, Cardiff

Zimmermann, E. (1983): Political Violence, Crises and Revolutions: Theories and Research. Schenkman, Cambridge, M.A.

Zimmermann, E. (1990): On the Outcomes of Revolutions: Some Preliminary Considerations. Sociological Theory. 8:33-47 